\title{
High frequency Barium profiles in shells of the Great Scallop Pecten maximus: a methodical long-term and multi-site survey in Western Europe
}

\author{
A. Barats ${ }^{1, *}$, D. Amouroux ${ }^{1}$, L. Chauvaud ${ }^{2}$, C. Pécheyran ${ }^{1}$, A. Lorrain $^{3}$, J. Thébault ${ }^{2, * *}$, T. M. Church ${ }^{4}$, and \\ O. F. X. Donard ${ }^{1}$
}

${ }^{1}$ Laboratoire de Chimie Analytique Bio-Inorganique et Environnement (LCABIE) - Institut Pluridisciplinaire de Recherche sur l'Environnement et les Matériaux (IPREM), UMR 5254 CNRS - Université de Pau et des Pays de l'Adour (UPPA), Hélioparc Pau-Pyrénées, 2 av. du Président Angot, 64053 Pau Cedex 9, France

${ }^{2}$ Laboratoire des sciences de l'Environnement MARin (LEMAR) - Institut Universitaire Européen de la Mer (IUEM), UMR 6539 CNRS - Université de Bretagne Occidentale (UBO), Technopole Brest-Iroise, Place Nicolas Copernic,

29280 Plouzané, France

${ }^{3}$ Institut de Recherche pour le Développement (IRD) - Laboratoire des sciences de l'Environnement MARin (LEMAR), Centre IRD de Brest, BP 70, 29280 Plouzané, France

${ }^{4}$ College of Marine and Earth Studies, University of Delaware, Newark, Delaware, 19716-3501, USA

*now at: Laboratoire de Radiochimie et des Sciences Analytiques et Environnement (LRSAE/EA 1175) - Université de Nice Sophia Antipolis (UNSA), 28 avenue Valrose, 06108 Nice Cedex 2, France

** now at: Johannes Gutenberg University, Institute of Geosciences, Department of Applied and Analytical Paleontology, Johann-Joachim-Becher-Weg 21, 55099 Mainz, Germany

Received: 23 July 2008 - Published in Biogeosciences Discuss.: 10 September 2008

Revised: 4 December 2008 - Accepted: 14 January 2009 - Published: 10 February 2009

\begin{abstract}
Skeletal barium/calcium $([\mathrm{Ba}] /[\mathrm{Ca}])_{\text {shell }}$ ratios were measured every third daily striae in 39 flat valves of the Great Scallop Pecten maximus collected in temperate coastal environments of Western Europe. A methodical evaluation of the $([\mathrm{Ba}] /[\mathrm{Ca}])_{\text {shell }}$ ratio was performed for the first time and demonstrates that $([\mathrm{Ba}] /[\mathrm{Ca}])_{\text {shell }}$ profiles are reproducible for several scallop individuals from the same population (2-year old; 3 shells/year), over a 7-year period (19982004), and from different coastal environments in France $\left(42-49^{\circ} \mathrm{N}\right)$. As previously determined in the shells of other bivalve species, $([\mathrm{Ba}] /[\mathrm{Ca}])_{\text {shell }}$ profiles generally exhibited a background ratio punctuated by two transient maxima occurring in early and late summer. Background partition coefficient $\left(\mathrm{D}_{\mathrm{Ba}}=0.11 \pm 0.03\right.$, in 2000) was similar to that previously reported in $P$. maximus shells, suggesting a direct shell uptake of dissolved seawater Ba (Gillikin et al., 2008). The 7-year survey in the Bay of Brest of the high frequency $([\mathrm{Ba}] /[\mathrm{Ca}])_{\text {shell }}$ profiles in the scallop's shell was exploited to better constrain both the occurrence and the amplitude of
\end{abstract}

the summer Ba relative enrichments as influenced by environmental processes. Seawater Ba contents in 2000 underlined significant particulate $\mathrm{Ba}$ inputs at the sediment water interface (SWI) during $([\mathrm{Ba}] /[\mathrm{Ca}])_{\text {shell }}$ peak events. These $\mathrm{Ba}$ inputs are thus suggested to be subsequently induced by a pelagic biogenic process, which mainly occurs under summer post-bloom conditions in relationship to the cycling of particulate organic matter and associated Ba. The long term survey reveals that such pelagic Ba cycling processes are responsible for particulate $\mathrm{Ba}$ inputs to the sediment water interface (SWI). Subsequent indirect Ba uptake by the bivalve results in higher $([\mathrm{Ba}] /[\mathrm{Ca}])_{\text {shell }}$ ratios, in that archived $\mathrm{Ba}$ within the shell cannot be used as a direct paleo productivity tracer. Our methodical approach, based on a multi-year and multi-site-survey of $([\mathrm{Ba}] /[\mathrm{Ca}])_{\text {shell }}$ ratio in Scallop bivalves, allows us to establish the potential application of such high frequency archives for further biogeochemical and ecological investigations of bivalves in the coastal environment.

\section{Correspondence to: D. Amouroux}

(david.amouroux@univ-pau.fr)

Published by Copernicus Publications on behalf of the European Geosciences Union. 


\section{Introduction}

Since 1965, trace elements in mollusc shells were investigated because bivalves form in their shells successive calcium carbonate layers, potential archives of conditions experienced by the organism during its life time (Dodd, 1965; Lorens and Bender, 1980; Klein et al., 1996a, 1996b; Stecher et al., 1996). The main aim of these studies was to use trace element records in shells as a bio indicator of environmental conditions. A recent increasing number of studies have investigated $\mathrm{Ba}$ content in biogenic carbonates, such as corals, foraminifera, and otoliths (Lea et al., 1989; Lea and Martin, 1996; McCulloch et al., 2003; Sinclair and McCulloch, 2004; de Vries et al., 2005; Sinclair, 2005). Coastal waters are enriched in $\mathrm{Ba}$ in the low to mid salinity ranges during estuarine mixing by either freshwater inputs of dissolved $\mathrm{Ba}$ or $\mathrm{Ba}$ release from river-born particulate phases (Coffey et al., 1997; Shaw et al., 1998; McCulloch et al., 2003). Alternatively $\mathrm{Ba}$ input can occur from the exchange of Ba-rich ground waters and pore waters within the tidal prism (Shaw et al., 1998). Coralline Ba content was reported as a proxy for discharge and/or sediment load in riverine systems (Sinclair and McCulloch, 2004; McCulloch et al., 2003). Some sharp Ba peaks in corals cannot however be assigned to any tracers of river discharge (Sinclair, 2005). Barium incorporation into carbonate parts of larval protoconchs or statoliths was also demonstrated to be promoted at lower temperature (Zacherl et al., 2003). In recent studies, there was much attention to the skeletal Ba content in mussels (Mytilus edulis; (Vander Putten et al., 2000; Gillikin et al., 2006), Isognomon ephippium; (Lazareth et al., 2003)), clams (Mercenaria mercenaria, Spisula solidissima, Arctica islandica, Saxidomus giganteus, Asiatic Corbicula fluminea; Fritz et al., 1990; Stecher et al., 1996; Epplé, 2004; Gillikin et al., 2005, 2008), and scallops (Pecten maximus, Comptopallium radula, Argopecten purpuratus; Lorrain, 2002; Thébault, 2005; Gillikin et al., 2008). In all these studies, $[\mathrm{Ba} / \mathrm{Ca}]_{\text {shell }}$ profiles were usually characterized by a relatively stable background ratio interrupted by sharp intense maxima. A simple interpretation achieved with several investigated bivalves (Mercenaria mercenaria, Mytilus edulis, Isognomon ephippium, Ensis siliqua) is also limited by an approximate dating of the shell record. In both lab and field experiments, the background $[\mathrm{Ba} / \mathrm{Ca}]_{\text {shell }}$ in the common mussel shell (Mytilus edulis) was demonstrated to track the $[\mathrm{Ba} / \mathrm{Ca}]_{\text {water }}$ aqueous concentration ratio (Gillikin et al., 2006). Considering the inverse relationship between $[\mathrm{Ba} / \mathrm{Ca}]_{\text {water }}$ and salinity, background $[\mathrm{Ba} / \mathrm{Ca}]_{\text {shell }}$ was considered as a specific indicator of salinity in estuarine environments (Gillikin et al., 2006). Barium was also established as a paleo productivity tracer in marine waters, suspended particles and sediments (Dymond and Collier, 1996; Paytan and Kastner, 1996). Stecher et al. (1996) postulated first that, in Mercenaria mercenaria and Spisula solidissima shells, these $[\mathrm{Ba} / \mathrm{Ca}]_{\text {shell }}$ peaks might be induced by the ingestion of high levels of particulate $\mathrm{Ba}$ in estuarine waters. Bivalves are nonselective filter feeders and can assimilate these Ba-rich particles. Once inside the digestive tract of the bivalve, Ba may be metabolised, at least in part, by being shunted to the extrapalleal fluid (EPF) and sequestered into the shell (Stecher et al., 1996; Vander Putten et al., 2000; Lorrain, 2002; Gillikin et al., 2006). Time resolved $[\mathrm{Ba} / \mathrm{Ca}]_{\text {shell }}$ peaks were suggested to be related to phytoplankton blooms (Stecher et al., 1996; Vander Putten et al., 2000; Lazareth et al., 2003). These Ba-rich particles were supposed to originate from diatom blooms as either biogenic matter, or barite precipitates (Stecher et al., 1996). Gillikin et al. (2006, 2008) indicated that these $[\mathrm{Ba} / \mathrm{Ca}]_{\text {shell }}$ peaks could not be used as a direct proxy of $[\mathrm{Ba} / \mathrm{Ca}]_{\text {water }}$ or phytoplankton production. These peaks were rather induced by ingestion of barite particles inputs to the sediment water interface (SWI) during the phytoplankton decay (Gillikin et al., 2006). Barium is recognized to be accumulated at high levels in phytoplankton, both in diatoms and in dinoflagellates (Fisher et al., 1991). A relatively large pool of labile $\mathrm{Ba}$ can be rapidly released during plankton decomposition and acts as the main source of Ba for barite formation in supersaturated microenvironments (Bishop, 1988; Ganeshram et al., 2003). Elevated levels of $\mathrm{Ba}$, both as suspended particulate $\mathrm{Ba}$ and sedimentary barite occurrs in high primary productivity oceanic regions (Dehairs et al., 1980; Bishop, 1988; Dehairs et al., 1991, 1997). Most probably, barite formation results from its passive precipitation through sulphate enrichment and/or release in barium containing biogenic material (Bishop, 1988; Stecher and Kogut, 1999; Jeandel et al., 2000; Ganeshram et al., 2003; Dehairs et al., 2000). The formation of specific aggregates or Ba-rich micro-environments is responsible for the Ba enrichment in biogenic particles (Bishop, 1988). These aggregates are related to the diatom extracellular polymeric substances (EPS) produced during summer blooms and their settling (Stecher and Kogut, 1999; Thornton, 2002). The subsequent vertical mixing and diatom decay provide a rapid flux and large abundance of biogenic particles transported down to the SWI (Sarthou et al., 2005). This was suggested to induce a sudden pulse of $\mathrm{Ba}$ to the epibenthic environment, subsequently ingested by molluscs to be incorporated into shells and recorded by $([\mathrm{Ba}] /[\mathrm{Ca}])_{\text {shell maxima (Gillikin et }}$ al., 2006). Phytoplankton Ba uptake and barite formation are however not sufficient to explain the vertical flux of $\mathrm{Ba}$ in oceanic waters (Sternberg et al., 2005). Barium is also scavenged in the presence of diatom biogenic particles or by adsorption onto mineral oxides (i.e. Fe, Mn) that contribute to significant Ba inputs to the SWI (Sternberg et al., 2005).

This study focuses on $\mathrm{Ba}$ content in the Great Scallop shell Pecten maximus (L.) to further establish how these bivalves can provide time resolved $([\mathrm{Ba}] /[\mathrm{Ca}])_{\text {shell }}$ profiles (daily scale) and valuable archives of environmental changes in temperate environments (Lorrain et al., 2000; Chauvaud et al., 1998, 2005; Lorrain et al., 2005; Barats, 2006; Barats et al., 2007, 2008; Gillikin et al., 2008 ). High frequency 
profiles of Ba content in the calcitic shell can be determined for each individual striae using laser ablation - inductively coupled plasma - mass spectrometry (LA-ICP-MS) (Barats et al., 2007). In this paper, the significance of $([\mathrm{Ba}] /[\mathrm{Ca}])_{\text {shell }}$ profiles in P. maximus is first evaluated for both background concentration and episodic sharp peaks in a single scallop population from the Bay of Brest (northwest France), among different coastal sites in western Europe, and over a 7-year period (1998-2004) in the Bay of Brest. Second, the demonstrated reproducibility, recurrence and ubiquity of $([\mathrm{Ba}] /[\mathrm{Ca}])_{\text {shell }}$ profiles is further utilized to clarify the biogeochemical processes influencing both the background and episodic sharp peaks of $([\mathrm{Ba}] /[\mathrm{Ca}])_{\text {shell }}$ content in scallop bivalves.

\section{Materials and methods}

\subsection{Study sites and scallop sampling}

Different sampling areas in Western Europe (Bay of Seine, Bay of Brest, Quiberon peninsula and Belle Ile, Ria de Vigo) were considered because they represent ecosystems with their own ecological characteristics (Barats, 2006). Shells originating from the Bay of Seine (France, English Channel, $49^{\circ} 30 \mathrm{~N}, 0^{\circ} 30 \mathrm{~W}$ ), Belle Ile and Quiberon area (France, Bay of Biscay, respectively, $47^{\circ} 20 \mathrm{~N}, 3^{\circ} 10 \mathrm{~W}$ and $47^{\circ} 30 \mathrm{~N}$, $3^{\circ} 00 \mathrm{~W}$ ) were sampled in open coastal ecosystems influenced by large estuarine inputs (respectively, Seine and Loire rivers) (Fig. 1). Shells sampled in coastal environments such as the Ria de Vigo (Spain, Atlantic Ocean, $42^{\circ} 10 \mathrm{~N}, 8^{\circ} 50 \mathrm{~W}$ ) or the Bay of Brest (France, Iroise Sea, Roscanvel bank, $48^{\circ} 20 \mathrm{~N}, 4^{\circ} 30 \mathrm{~W}$ ) were subjected to low anthropogenic inputs. In this study, the main sampling site is the Bay of Brest (Fig. 1): a shallow embayment with more than a half of its surface $\left(180-\mathrm{km}^{2}\right)$ and with depth of less than $5 \mathrm{~m}$. The hydrodynamics of this ecosystem is mainly influenced by tidal exchange with the Iroise Sea, but also by freshwater input mainly by two small riverine watersheds $(80 \%)$ : the Aulne $\left(1842 \mathrm{~km}^{2}\right)$ with monthly flow rate ranging from 2 to $52 \mathrm{~m}^{3} / \mathrm{s}$ and averaging $22 \mathrm{~m}^{3} / \mathrm{s}$, and the Elorn $\left(402 \mathrm{~km}^{2}\right)$ with monthly flow rate ranging from 1 to $12 \mathrm{~m}^{3} / \mathrm{s}$ and averaging $5.6 \mathrm{~m}^{3} / \mathrm{s}$. The sampling area (Roscanvel) is $30 \mathrm{~m}$ deep where the bottom consists of mixed sediments (mud, sand) and selected because scallop density is one of the highest in the Bay of Brest (Chauvaud et al., 2000, 2005).

Three replicates of live juvenile $P$. maximus specimens were collected for each year and site (except in 2002 in the Bay of Brest, $n=2$ ) during the late autumn period by SCUBA diving in the Bay of Brest and by dredging for other sites. Only the juvenile stage of the shells (the second year of growth) was examined because it exhibits the longest annual growth period. An exception was made for a three-year old P. maximus specimen collected in the Bay of Brest in 2003 to examine its third year of growth. The shells were isolated and

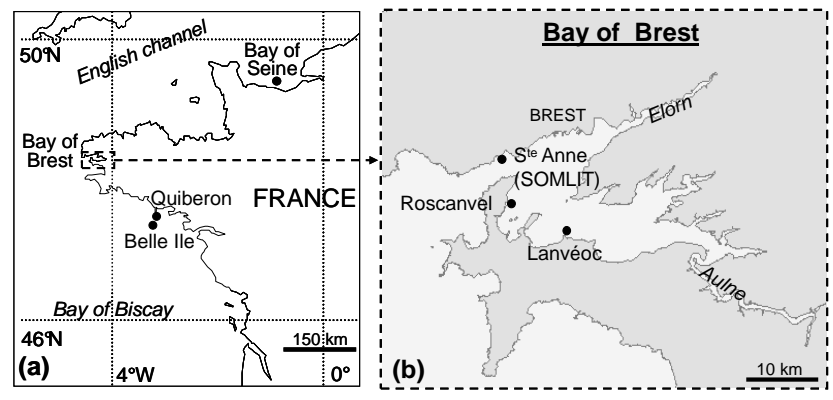

Fig. 1. Maps of the investigated area (Atlantic Coast, France) showing the sampling zones: (a) the Bay of Seine $\left(49^{\circ} 30 \mathrm{~N}, 0^{\circ} 30 \mathrm{~W}\right)$, the Bay of Brest $\left(48^{\circ} 20 \mathrm{~N}, 4^{\circ} 30 \mathrm{~W}\right)$, Belle Ile $\left(47^{\circ} 20 \mathrm{~N}, 3^{\circ} 10 \mathrm{~W}\right)$ and Quiberon $\left(47^{\circ} 30 \mathrm{~N}, 3^{\circ} 00 \mathrm{~W}\right)$; (b) the Bay of Brest in detail with all the investigated sites (Roscanvel for the sampling, and the others for regular measurements of environmental parameters).

cleaned by submerging in glacial acetic acid (Merck, analytical grade) for $60 \mathrm{~s}$ to remove bio-fouling, rinsed with Milli-Q water $(R=18.2 \mathrm{M} \Omega . \mathrm{cm})$ and dried. For convenience in visualizing the growth striae, only the flat valve was considered for LA-ICP-MS analysis. A $45 \times 10 \mathrm{~mm}^{2}$ cross section was cut from each shell using a diamond saw to fit into an ablation chamber.

2.2 Determination of $\mathrm{Ba}$ concentrations in shells by Laser Ablation - Inductively Coupled Plasma - Mass Spectrometry (LA-ICP-MS)

Quantitative analyses of 39 shells were performed by LAICP-MS method consisting of coupling a UV laser ablation unit (LSX 100 UV $266 \mathrm{~nm}$, Cetac Tech.) to an ICP-MS (X7 serie, Thermo Fisher). The methodology and validation were described elsewhere and summarized here (Barats et al., 2007). Samples were analysed during $2 \mathrm{~min}$ at a scan speed rate of $5 \mu \mathrm{m} / \mathrm{s}$. For shell analyses, a pre cleaning ablation of the calcite surface was conducted to avoid surface contamination (Stecher et al., 1996; Vander Putten et al., 1999; Lazareth et al., 2003; Wyndham et al., 2004). This pre cleaning step consisted in a quick (around 20s) pre-ablation of shell surface at a rate of $50 \mu \mathrm{m} / \mathrm{s}$. Twenty-eight isotopes including ${ }^{135,137,138} \mathrm{Ba},{ }^{55} \mathrm{Mn}$ and ${ }^{43} \mathrm{Ca}$ were analysed. The intensity of each isotope signal was systematically normalized against the ${ }^{43} \mathrm{Ca}$ signal to compensate for instrumental drift and instability. An external calibration was performed with lab prepared $\mathrm{CaCO}_{3}$ standards containing Ba concentrations ranging from 0.005 to $19.6 \mu \mathrm{g} / \mathrm{g}$ (Barats et al., 2007). The Ba calibration curve displayed a good linearity with a regression coefficient $r^{2}$ above 0.998 (Barats et al., 2007). The detection limit was about $3.3 \mathrm{ng} / \mathrm{g}$, and the relative standard deviations obtained for both analytical repeatability ( 5 integration zones during 1 analysis) and reproducibility (5 successive independent analyses) were below 5\% (Barats et al., 2007). 
Analytical performances obtained for Mn were previously presented (Barats et al., 2007, 2008). The ([Ba]/[Ca] $)_{\text {shell }}$ or $([\mathrm{Mn}] /[\mathrm{Ca}])_{\text {shell }}$ ratios were calculated by dividing shell $\mathrm{Ba}$ or Mn concentrations by the Ca concentration in the shell (40\%) and expressed in $\mu \mathrm{mol} / \mathrm{mol}$. Mollusc shells were recognized to contain less than $5 \%$ of organic matrix in calcite or aragonite shells (Carroll et al., 2006; Levi-Kalisman et al., 2001). The shell is thus composed by minimum $95 \%$ of $\mathrm{CaCO}_{3}$, i.e. a minimum shell Ca content of $38 \%$. In comparison with the Ca concentration of $40 \%$, the error is only of $5 \%$. This study thus used a shell Ca content of $40 \%$ because scallop shells have a calcite structure. While the exact percentage of organic matter remains unknown, yet likely less than 5\%, the analytical error will be negligible. A recent study of Takesue et al. (2008) revealed higher organic content in clams (19\%), but they demonstrated also that Ba assay in shell content was unchanged by the removal of organic matter. This conclusion underscores that while Ba occurs exclusively in shell aragonite of clams, the analytical result agrees with the use of $\mathrm{Ca}$ concentration about $40 \%$ to calculate our $([\mathrm{Ba}] /[\mathrm{Ca}])_{\text {shell }}$ ratios.

Shell analyses were performed each third striae during the shell growth period (from April to November) to limit the analysis time to approximately $5 \mathrm{~h}$ per shell. A date of formation was assigned to each ablated sample, by backdating from the harvest date, based on the daily periodicity of the striae formation in P. maximus. An evaluation of the shell growth rate (dorso-ventral linear extension of the shell per unit time), expressed in $\mu \mathrm{m} / \mathrm{d}$, was also performed for each shell by measuring distances between successive striae (growth increment width) using an image analysis technique (Chauvaud, 1998). For each shell analysis, a profile of shell growth rate and a profile of $([\mathrm{Ba}] /[\mathrm{Ca}])_{\text {shell }}$ ratio were obtained. For each year and site, a mean shell growth rate profile and a mean $([\mathrm{Ba}] /[\mathrm{Ca}])_{\text {shell }}$ were then defined averaging the results of 3 shells from a same scallop population. Due to the uncertainties from the backdating of analysed striae and those from the intershell comparison, the uncertainty in the date for mean shell profiles was estimated to range from 1 to 7 days.

\subsection{Environmental monitoring database}

$([\mathrm{Ba}] /[\mathrm{Ca}])_{\text {shell }}$ time series were compared with environmental variables that may influence Ba biogeochemical cycle at the SWI. The Bay of Brest (Roscanvel station) was mainly investigated because of the regular environmental monitoring and the long time series obtained by shell analyses (1998 to 2004). Regular measurements (2-3 days resolution) of Ba and $\mathrm{Mn}$ concentrations in dissolved $(<0.6 \mu \mathrm{m}$, Nucleopore) and particulate phases from bottom seawater $(1 \mathrm{~m}$ above the SWI) were also performed at the sampling site (Roscanvel) in 2000 (from February to December). Filtrated samples (dissolved seawater phase) were acidified in $2 \% \mathrm{HNO}_{3}(69-70 \%$ Suprapur, Merck) and diluted 30 times to determine concen- trations of dissolved elements. Two internal standards were added ( $\mathrm{Y}$ and $\mathrm{Bi})$ in diluted samples. Elemental concentrations $(\mathrm{Ba}, \mathrm{Mn}, \ldots)$ were then determined by ICP-MS (X7 series, Thermo Fisher) by an external and internal calibration. Particulate samples (filters) were digested in closed vials (Savilex, PFA) by an acid mixture $\left(1.5 \mathrm{ml} \mathrm{HCl}, 1 \mathrm{ml} \mathrm{HNO}_{3}\right.$, $0.5 \mathrm{ml} \mathrm{HF}$; suprapur quality) at $95^{\circ} \mathrm{C}$ during one night. The digested samples were evaporated to dryness at $110^{\circ} \mathrm{C}$ under a laminar hood to eliminate the matrix. The residues were dissolved in $2.5 \mathrm{ml}$ of nitric acid solution $\left(\mathrm{HNO}_{3} 2 \%\right)$ and the volumes were adjusted to $11 \mathrm{ml}$. These samples were analyzed by ICP-AES (THERMO Optek Iris Advantage, Thermo Fisher) at the Royal Museum for Central Africa (Belgium). Samples were spiked with a mixture of internal standards $(\mathrm{Au}, \mathrm{Y})$ before its introduction into the spectrometer to compensate instrumental drift and instability. All these experiments were performed under clean conditions (clean vials, laminar flood, blank procedure...).

$([\mathrm{Ba}] /[\mathrm{Ca}])_{\text {shell }}$ time series were also compared with an environmental database: hydrological ( $\mathrm{S}, \mathrm{T}$, suspended particulate matter), chemical $\left(\mathrm{O}_{2}, \mathrm{NO}_{3}^{-}, \mathrm{NO}_{2}^{-}, \mathrm{NH}_{4}^{+}, \mathrm{PO}_{4}^{3-}\right.$, $\mathrm{Si}(\mathrm{OH})_{4}$, particulate organic carbon (POC) or nitrogen $(\mathrm{PON}))$ and biological parameters. Biological parameters include total phytoplankton biomass, as reflected by chlorophyll- $a$ and abundance of phytoplankton species. These measurements were performed in the Bay of Brest at the "Sainte Anne" site near to Roscanvel sampling zone, as part of monitoring activities lead by the Intitut Universitaire Européen de la Mer (http://www.univ-brest.fr/IUEM/ observation/observation_iroise.htm; Fig. 1). All these measurements were performed at a weekly resolution. Nutrient dynamics in SOMLIT station were previously demonstrated to reflect environmental conditions in Roscanvel (Lorrain, 2002). Phytoplankton composition (a hundred species) were monitored from 1998 to 2002 at Lanvéoc $\left(48^{\circ} 18 \mathrm{~N}, 4^{\circ} 27 \mathrm{~W}\right)$, located near to Roscanvel, as a part of the littoral environment monitoring program lead by the Institut Français de Recherche pour l'Exploitation de la MER (IFREMER database, http://www.ifremer.fr/envlit/), and from 2003 to 2004 , at the seawater surface $(0-1 \mathrm{~m})$ in a reference SOMLIT station (Service d'Observation en Milieu LITtoral: $48^{\circ} 22 \mathrm{~N}$, $4^{\circ} 33 \mathrm{~W}$ ) (Fig. 1). Phytoplankton identifications were performed in surface seawater $(0-1 \mathrm{~m})$ and every 15 days, except in 2004 (weekly resolution).

\subsection{Statistical analyses}

A statistical data treatment was performed to highlight environmental parameters influencing the occurrence and the amplitude of $([\mathrm{Ba}] /[\mathrm{Ca}])_{\text {shell }}$ peaks. $([\mathrm{Ba}] /[\mathrm{Ca}])_{\text {shell maxi- }}$ mum events from their beginning to their end, usually last 20 days, whatever year studied. Averaged environmental parameters were thus examined over different periods: 4 weeks before- 1 week after $(-4 \mathrm{~W}+1, \mathrm{~W}), 3$ weeks before1 week after $(-3 \mathrm{~W}+1 \mathrm{~W}), 2$ weeks before-1 week after 
Table 1. : Intershell comparison of ([Ba]/[Ca] $)_{\text {shell }}$ profiles and interannual comparison (1998-2004) of both mean background and mean peak intensity (named by the time order of the peak) of $([\mathrm{Ba}] /[\mathrm{Ca}])_{\text {shell }}$ ratios $(n=3)$ in scallops from the Bay of Brest.

\begin{tabular}{|c|c|c|c|c|c|c|c|c|c|c|c|c|c|c|}
\hline \multirow[b]{2}{*}{ Year } & \multicolumn{4}{|c|}{$\begin{array}{c}\text { Intershell reproducibility of Ba profiles } \\
\text { Correlation coefficients }\end{array}$} & \multicolumn{4}{|c|}{$\begin{array}{l}\text { Background shell } \mathrm{Ba} / \mathrm{Ca} \\
\quad \text { ratios }(\mu \mathrm{mol} / \mathrm{mol})\end{array}$} & \multicolumn{6}{|c|}{ Maxima of shell $\mathrm{Ba} / \mathrm{Ca}$ ratios $(\mu \mathrm{mol} / \mathrm{mol})$} \\
\hline & 1 vs 2 & 1 vs 3 & 2 vs 3 & $p$ & Mean & & SD & $\% \mathrm{RSD}$ & & Date $( \pm 3 \mathrm{~d})$ & Mean & & SD & $\%$ RSD \\
\hline $\begin{array}{l}1998 \\
(n=3)\end{array}$ & 0.72 & 0.78 & 0.95 & $<0.05$ & 0.526 & \pm & 0.074 & 14 & $\begin{array}{l}\text { peak } 1 \\
\text { peak } 2\end{array}$ & $\begin{array}{l}12 / 06 / 1998 \\
04 / 09 / 1998\end{array}$ & $\begin{array}{c}4.67 \\
0.898\end{array}$ & $\begin{array}{l} \pm \\
\pm\end{array}$ & $\begin{array}{c}1.90 \\
0.314\end{array}$ & $\begin{array}{l}41 \\
35\end{array}$ \\
\hline $\begin{array}{l}1999 \\
(n=3)\end{array}$ & 0.92 & 0.95 & 0.96 & $<0.05$ & 0.377 & \pm & 0.031 & 8 & $\begin{array}{l}\text { peak } 1 \\
\text { peak } 2\end{array}$ & $\begin{array}{l}18 / 06 / 1999 \\
19 / 07 / 1999\end{array}$ & $\begin{array}{l}1.27 \\
2.12\end{array}$ & $\begin{array}{l} \pm \\
\pm\end{array}$ & $\begin{array}{l}0.48 \\
0.84\end{array}$ & $\begin{array}{l}38 \\
40\end{array}$ \\
\hline $\begin{array}{l}2000 \\
(n=3)\end{array}$ & 0.48 & 0.22 & 0.82 & $<0.09$ & 0.561 & \pm & 0.057 & 10 & $\begin{array}{l}\text { peak } 1 \\
\text { peak } 2\end{array}$ & $\begin{array}{l}23 / 07 / 2000 \\
26 / 08 / 2000\end{array}$ & $\begin{array}{l}1.03 \\
0.73\end{array}$ & $\begin{array}{l} \pm \\
\pm\end{array}$ & $\begin{array}{l}0.03 \\
0.04\end{array}$ & $\begin{array}{l}3 \\
5\end{array}$ \\
\hline $\begin{array}{l}2001 \\
(n=3)\end{array}$ & 0.18 & 0.24 & 0.46 & $<0.2$ & 0.657 & \pm & 0.101 & 15 & $\begin{array}{l}\text { peak } 1 \\
\text { peak } 2\end{array}$ & $\begin{array}{l}22 / 07 / 2001 \\
31 / 07 / 2001\end{array}$ & $\begin{array}{c}0.971 \\
1.39\end{array}$ & $\begin{array}{l} \pm \\
\pm\end{array}$ & $\begin{array}{c}0.431 \\
0.91\end{array}$ & $\begin{array}{l}44 \\
65\end{array}$ \\
\hline $\begin{array}{l}2002 \\
(n=2)\end{array}$ & 0.88 & - & - & $<0.05$ & 0.533 & \pm & 0.102 & 19 & $\begin{array}{l}\text { peak } 1 \\
\text { peak } 2 \\
\text { peak } 3 \\
\text { peak } 4\end{array}$ & $\begin{array}{l}14 / 06 / 2002 \\
01 / 07 / 2002 \\
26 / 07 / 2002 \\
20 / 08 / 2002\end{array}$ & $\begin{array}{l}1.86 \\
1.31 \\
1.55 \\
2.83\end{array}$ & $\begin{array}{l} \pm \\
\pm \\
\pm \\
\pm\end{array}$ & $\begin{array}{l}0.60 \\
0.42 \\
0.18 \\
0.55\end{array}$ & $\begin{array}{l}32 \\
32 \\
12 \\
19\end{array}$ \\
\hline $\begin{array}{l}2003 \\
(n=3)\end{array}$ & 0.93 & 0.96 & 0.87 & $<0.05$ & 0.535 & \pm & 0.134 & 25 & $\begin{array}{l}\text { peak } 1 \\
\text { peak } 2\end{array}$ & $\begin{array}{l}20 / 07 / 2003 \\
26 / 08 / 2003\end{array}$ & $\begin{array}{l}3.80 \\
1.72\end{array}$ & $\begin{array}{l} \pm \\
\pm\end{array}$ & $\begin{array}{l}0.74 \\
0.12\end{array}$ & $\begin{array}{c}20 \\
7\end{array}$ \\
\hline $\begin{array}{l}2004 \\
(n=3)\end{array}$ & 0.44 & 0.78 & 0.30 & $<0.05$ & 0.745 & \pm & 0.175 & 24 & $\begin{array}{l}\text { peak } 1 \\
\text { peak } 2\end{array}$ & $\begin{array}{l}18 / 06 / 2004 \\
05 / 09 / 2004\end{array}$ & $\begin{array}{l}2.25 \\
1.26\end{array}$ & $\begin{array}{l} \pm \\
\pm\end{array}$ & $\begin{array}{l}0.99 \\
0.38\end{array}$ & $\begin{array}{l}44 \\
30\end{array}$ \\
\hline
\end{tabular}

$(-2 \mathrm{~W}+1 \mathrm{~W}), 1$ week before- 1 week after $(-1 \mathrm{~W}+1 \mathrm{~W})$ the maximum $([\mathrm{Ba}] /[\mathrm{Ca}])_{\text {shell }}$ ratios. The choice of such integration periods around the maximum of $([\mathrm{Ba}] /[\mathrm{Ca}])_{\text {shell }}$ was consistent with the lower resolution obtained for most of environmental parameters and the uncertainty due to the backdating of shell striae. These integration periods took into account an eventual lag between changes in the water column, at the SWI, and its further transcription within the shell. This allowed a good overlap between $([\mathrm{Ba}] /[\mathrm{Ca}])_{\text {shell }}$ maxima and environmental datasets. The influence of transient events was tested taking into account the maximum value during the considered period.

Bravais Pearson tests and multiple regression analyses were performed with Stabox Pro software for Windows Ver. 6 (Grimmer Software, France). Bravais Pearson tests were used to emphasize univariate correlations between the amplitude of $([\mathrm{Ba}] /[\mathrm{Ca}])_{\text {shell }}$ maxima and others variables. Multiple regression analyses were considered to express the amplitude of $([\mathrm{Ba}] /[\mathrm{Ca}])_{\text {shell }}$ maxima according to several independent factors. The relationships were significant if the probability was below $p<0.05$, and moderate-to-strong if $r^{2}$ $>0.7$. If all the $([\mathrm{Ba}] /[\mathrm{Ca}])_{\text {shell }}$ maxima agreed with the relationship, the Cook's distance was below $d_{\text {cook }}<1$.

\section{Results and discussion}

3.1 Definition of a general pattern for $([\mathrm{Ba}] /[\mathrm{Ca}])_{\text {shell }}$ profiles

3.1.1 Reproducibility of background and episodic maxima of $([\mathrm{Ba}] /[\mathrm{Ca}])_{\text {shell }}$ ratios among a single scallop population

The variations of $([\mathrm{Ba}] /[\mathrm{Ca}])_{\text {shell }}$ ratios were examined in 2003, for 2-year old shells and for 3-year old shells from the Bay of Brest (Fig. 2). Two-year old scallops, analysed for its juvenile stage, reveal a high reproducibility of $([\mathrm{Ba}] /[\mathrm{Ca}])_{\text {shell }}$ profiles $\left(r^{2}>0.78, \quad p<0.05, n>60\right)$ (Table 1, Fig. 2). Background $([\mathrm{Ba}] /[\mathrm{Ca}])_{\text {shell }}$ ratio was obtained after the exclusion of peculiar data (i.e. $\mathrm{Ba} / \mathrm{Ca}$ peaks) exhibiting higher ratio than the average values plus 3 times the standard deviation. A mean $([\mathrm{Ba}] /[\mathrm{Ca}])_{\text {shell }}$ profiles exhibits a background ratio of $0.535 \pm 0.134 \mu \mathrm{mol} / \mathrm{mol}$, and two significant enrichments from July to August (respectively, $3.80 \pm 0.74 \mu \mathrm{mol} / \mathrm{mol}$ the 20th of July, and $1.72 \pm 0.12 \mu \mathrm{mol} / \mathrm{mol}$ the 26th of August) (Fig. 2b, Table 1).

This $([\mathrm{Ba}] /[\mathrm{Ca}])_{\text {shell }}$ profile demonstrates a high inter individual reproducibility among scallops of the same age for both background content and summer peak events with similar occurrence dates and amplitudes (Fig. 2a). The reproducibility of $([\mathrm{Ba}] /[\mathrm{Ca}])_{\text {shell }}$ ratios was previously demonstrated for 2-year old scallops from the Bay of Brest (Barats et al., 2007). Analyses of a 3-year old scallop from the same population (shells collected the same year and site) were also performed for the third year of the shell growth. 

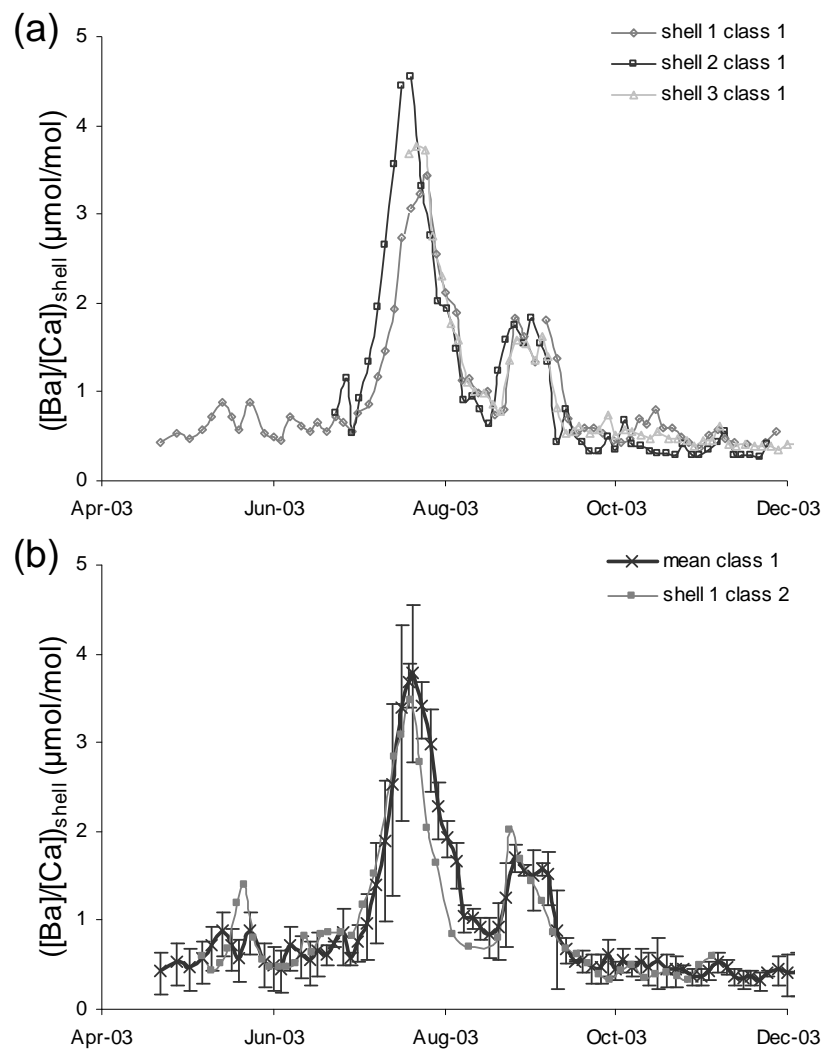

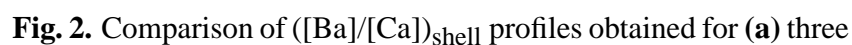
2-year old scallop shells; (b) the mean profile of these 3 juvenile shells and one of 3-year old scallop shell collected in the Bay of Brest (Roscanvel) during the year 2003 to evaluate the inter shell reproducibility of $\mathrm{Ba}$ variations.

The $([\mathrm{Ba}] /[\mathrm{Ca}])_{\text {shell }}$ ratios for this 3-year old scallop reveal a similar pattern to those obtained for the 2-year old scallops (Fig. 2b). This result suggests that background level or the occurrence of maxima of $([\mathrm{Ba}] /[\mathrm{Ca}])_{\text {shell }}$ ratios are not related to specific age-dependent physiological effects. In fact $([\mathrm{Ba}] /[\mathrm{Ca}])_{\text {shell }}$ profiles in 2003 for 2- and 3-year old scallops from the Bay of Brest (Fig. 2b) are compared to those previously reported for this location (Gillikin et al., 2008) . These results are remarkably in agreement and demonstrate first the precision of the matrix matched LA-ICP-MS technique (versus acid dissolution - High Resolution ICP-MS), and second the significant reproducibility of $([\mathrm{Ba}] /[\mathrm{Ca}])_{\text {shell }}$ profiles among the same scallop population irrespective of the scallop age.
3.1.2 Recurrence of $([\mathrm{Ba}] /[\mathrm{Ca}])_{\text {shell }}$ profiles over a 7-year period (1998-2004, Bay of Brest) and among different coastal sites (Western Europe)

The $([\mathrm{Ba}] /[\mathrm{Ca}])_{\text {shell }}$ profiles were then examined on a specific population (Bay of Brest) over a 7-year survey. Inter-shell comparison of $([\mathrm{Ba}] /[\mathrm{Ca}])_{\text {shell }}$ profiles obtained for 3 scallop replicates confirms first the significant reproducibility of these profiles among a single population $(p<0.05, n>60$, except in 2000 and 2001) (Table 1). Variations of mean $([\mathrm{Ba}] /[\mathrm{Ca}])_{\text {shell }}$ ratios $(n=3)$ over the 7 -year period reveal a common pattern with a stable background ratio punctuated by 2 summer maxima with specific year-dependant intensities (Fig. 3, Table 1). The background $([\mathrm{Ba}] /[\mathrm{Ca}])_{\text {shell }}$ ratio is about $0.56 \pm 0.12 \mu \mathrm{mol} / \mathrm{mol}$ and rather homogenous along the year $(\% \mathrm{RSD}<20)$. The first summer $([\mathrm{Ba}] /[\mathrm{Ca}])_{\text {shell }}$ peak occurs from mid June to July and the second one from end July to early September. The year 2000 exhibits the weakest maxima of $([\mathrm{Ba}] /[\mathrm{Ca}])_{\text {shell }}$ ratios $(1.03-0.73 \mu \mathrm{mol} / \mathrm{mol})$. The year 2002 remains unusual with four $([\mathrm{Ba}] /[\mathrm{Ca}])_{\text {shell }}$ peaks $(1.86,1.31,1.55,2.83 \mu \mathrm{mol} / \mathrm{mol})$.

The background and maximum $(\mathrm{Ba} / \mathrm{Ca})_{\text {shell }}$ ratios obtained in different ecosystems (Bay of Seine, Bay of Brest, Belle Ile, Quiberon, Ria de Vigo) were summarized in Table 2. This inter-site study shows a similar $([\mathrm{Ba}] /[\mathrm{Ca}])_{\text {shell }}$ pattern with background content ranging from 0.44 to $0.68 \mu \mathrm{mol} / \mathrm{mol}$ and ubiquitous maxima in summer. The range of maximum $([\mathrm{Ba}] /[\mathrm{Ca}])_{\text {shell }}$ ratios is similar in all locations $(0.73-5.3 \mu \mathrm{mol} / \mathrm{mol})$ corresponding to a $1.3-9$ fold enrichment. These results characterize a recurrent $([\mathrm{Ba}] /[\mathrm{Ca}])_{\text {shell }}$ profile typology at all sites and years, with a constant background content punctuated by a first intensive peak in early summer (mid-June to July) and a second weaker one in late summer (August to early September).

\subsubsection{Comparability of archived Ba signals in other bivalve shells}

These recurrent $([\mathrm{Ba}] /[\mathrm{Ca}])_{\text {shell }}$ profiles observed for $P$. max imus shells are compared to similar ones recorded in bivalves from other coastal environments (Table 2). The background $([\mathrm{Ba}] /[\mathrm{Ca}])_{\text {shell }}$ ratio and summer peaks (max. 9 times the background in $P$. maximus shells and up to 34 times the background for other bivalves) are slightly lower in $P$. maximus shells. Differences in $([\mathrm{Ba}] /[\mathrm{Ca}])_{\text {shell }}$ content can be related to the bivalve species, its physiology, or differences in analytical methods. For example, the maximum intensity of $([\mathrm{Ba}] /[\mathrm{Ca}])_{\text {shell }}$ ratios is particularly high in mussels and clams (up to $20 \mu \mathrm{mol} / \mathrm{mol}$ ). This may be explained by the preferential precipitation of $\mathrm{Ba}$ under the aragonite structure of $\mathrm{CaCO}_{3}$ (Rimstidt et al., 1998). Higher $([\mathrm{Ba}] /[\mathrm{Ca}])_{\text {shell }}$ content can be influenced by the structure of this bivalve (aragonite or calcite). Gillikin et al. (2008) demonstrated however that shell mineralogy has no effect on $([\mathrm{Ba}] /[\mathrm{Ca}])_{\text {shell }}$ ratios (Gillikin et al., 2008). 

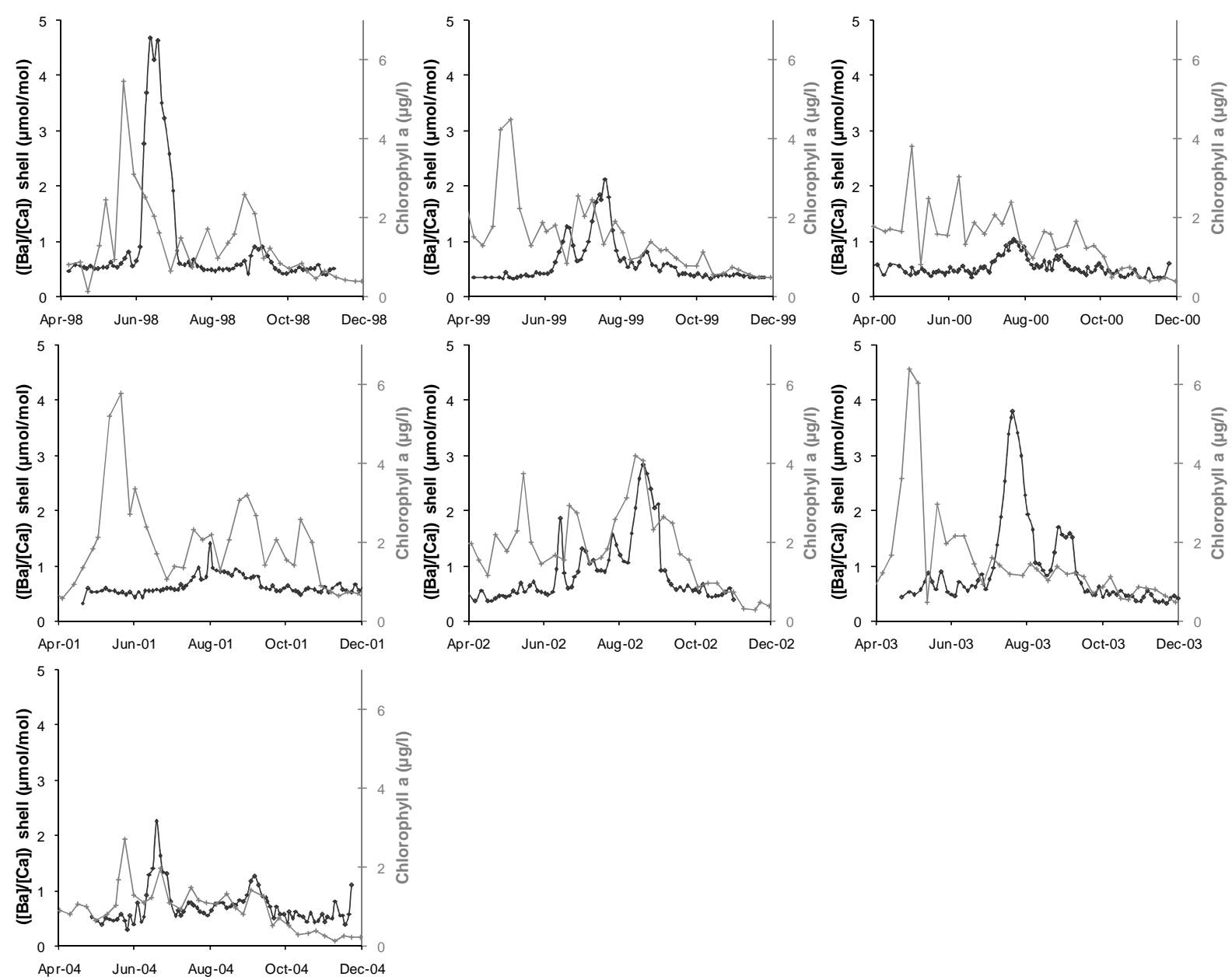

Fig. 3. Variations of mean $([\mathrm{Ba}] /[\mathrm{Ca}])_{\text {shell }}$ ratios (3 shells per year; except in 2002, $n=2$; black profile) according to the chlorophyll- $a$ concentration ( $\mu \mathrm{g} / \mathrm{l}$, grey profile), over 7-year period (1998-2004) in scallops from Roscanvel station (Bay of Brest, France).

Differences in calibration steps can also induce differences in $([\mathrm{Ba}] /[\mathrm{Ca}])_{\text {shell }}$ ratios. Quantitative Ba analyses were performed with LA-ICP-MS using external calibrations with NIST glass standard reference materials at a minimum of $41 \mu \mathrm{g} / \mathrm{g}$ of Ba (Carré et al., 2006; Lazareth et al., 2003; Pearce and Mann, 2006; Stecher et al., 1996; Vander Putten et al., 1999, 2000). Such external calibration is probably not suitable to accurately measure shell $\mathrm{Ba}$ concentrations ranging from 1 to $10 \mu \mathrm{g} / \mathrm{g}$, especially considering the different matrix properties and response between glasses and $\mathrm{CaCO}_{3}$ shells when using some laser ablation units (Belloto and Mikeley, 2000; Barats et al., 2007). Based on these conclusions, external calibrations with $\mathrm{CaCO}_{3}$ standards was thus preferred in this study and others (Belloto and Mikeley, 2000; Thébault, 2005; Gillikin et al., 2006; Barats et al., 2007). Finally, taking into account the accurate dating of this study, and differences in analytical methods and in bivalve species, all these studies agree with a common profile of $([\mathrm{Ba}] /[\mathrm{Ca}])_{\text {shell }}$ ratio in bivalves; widespread over the world a background ratio punctuated by sharp summer episodic peaks. This observation thus supports specific and ubiquitous processes involved in the increase of $([\mathrm{Ba}] /[\mathrm{Ca}])_{\text {shell }}$ ratio, which must be directly related to changing conditions in the scallop environment.

\subsection{Biogeochemical processes influencing $([\mathrm{Ba}] /[\mathrm{Ca}])_{\text {shell }}$ profiles}

\subsection{1 $([\mathrm{Ba}] /[\mathrm{Ca}])_{\text {shell }}$ background content as an indicator of $\mathrm{Ba}$ aqueous concentration}

The $([\mathrm{Ba}] /[\mathrm{Ca}])_{\text {shell }}$ background ratios in P. maximus shells were measured in the Bay of Brest over a 7-year period (Table 1). This reveals an average ratio of $0.56 \pm 0.12 \mu \mathrm{mol} / \mathrm{mol}$. $([\mathrm{Ba}] /[\mathrm{Ca}])$ ratio in the Bay of Brest was determined in both dissolved and particulate seawater collected at $1 \mathrm{~m}$ above the SWI from March to September 2000 at intervals of 2 or 3 times/week, except from 24 July to the 9 September (Lorrain, 2002). ([Ba]/[Ca] $)_{\text {shell }}$ profiles 
Table 2. : Barium archives in different bivalve shells according to different ecosystems. Both background and maximum $(\mathrm{Ba} / \mathrm{Ca})_{\text {shell }}$ ratios are examined. The period of $(\mathrm{Ba} / \mathrm{Ca})_{\text {shell }}$ maxima are also shown.

\begin{tabular}{|c|c|c|c|c|c|c|c|c|c|c|c|}
\hline Bivalve & Species & $\begin{array}{l}\text { Structure of } \\
\text { precipitation }\end{array}$ & Location & $\begin{array}{l}\text { Ecosystem } \\
\text { type }\end{array}$ & Time resolution & $\begin{array}{l}\text { Investigated } \\
\text { period }\end{array}$ & $\begin{array}{l}\text { Background } \mathrm{Ba} / \mathrm{Ca} \\
\text { ratios }(\mu \mathrm{mol} / \mathrm{mol})\end{array}$ & $\begin{array}{l}\text { Ba enrichment } \\
\text { period }\end{array}$ & $\begin{array}{l}\text { Maximum Ba/Ca } \\
\operatorname{ratios}(\mu \mathrm{mol} / \mathrm{mol})\end{array}$ & $\begin{array}{l}{[\mathrm{Ba}]_{\max } /} \\
{[\mathrm{Ba}]_{\text {bkg }}}\end{array}$ & Références \\
\hline \multirow[t]{7}{*}{ Scallop } & $\begin{array}{l}\text { Pecten } \\
\text { maximus }\end{array}$ & calcite & $\begin{array}{l}\text { Bay of Brest, } \\
\text { France }\end{array}$ & $\begin{array}{l}\text { Coastal, } \\
\text { temperate }\end{array}$ & 3 days + dating & 1998-2004 & $0.56 \pm 0.12$ & $\begin{array}{l}\text { late June to } \\
\text { early September }\end{array}$ & $0.73-4.7$ & $1.3-9$ & This study* \\
\hline & & & $\begin{array}{l}\text { Bay of Brest, } \\
\text { France }\end{array}$ & $\begin{array}{l}\text { Coastal, } \\
\text { temperate }\end{array}$ & 3 days + dating & 2000 & $\begin{array}{l}\text { Qualitative } \\
\text { analysis }\end{array}$ & July-August & $\begin{array}{l}\text { Qualitative } \\
\text { analysis }\end{array}$ & $5-9$ & Lorrain (2002) \\
\hline & & & $\begin{array}{l}\text { Bay of Brest, } \\
\text { France }\end{array}$ & $\begin{array}{l}\text { Coastal, } \\
\text { temperate }\end{array}$ & 3 days + dating & 2003 & 0.7 & July-August & 4 & 6 & Gillikin et al. (2008)* \\
\hline & & & $\begin{array}{l}\text { Quiberon, } \\
\text { France }\end{array}$ & $\begin{array}{l}\text { Coastal, } \\
\text { temperate }\end{array}$ & 3 days + dating & 2000 & $0.68 \pm 0.12$ & $\begin{array}{l}\text { Late May- } \\
\text { July }\end{array}$ & $1.3-1.8$ & $2-3$ & This study* \\
\hline & & & $\begin{array}{l}\text { Belle Ile, } \\
\text { France }\end{array}$ & $\begin{array}{l}\text { Coastal, } \\
\text { temperate }\end{array}$ & 3 days + dating & 1999-2001 & $0.68 \pm 0.13$ & $\begin{array}{l}\text { June- } \\
\text { early August }\end{array}$ & $0.76-5.3$ & $2-7$ & This study* \\
\hline & & & $\begin{array}{l}\text { Bay of Seine, } \\
\text { France }\end{array}$ & $\begin{array}{l}\text { Coastal, } \\
\text { temperate }\end{array}$ & 3 days + dating & 2004 & $0.44 \pm 0.04$ & May & 1.36 & 3 & This study* \\
\hline & & & $\begin{array}{l}\text { Ria de Vigo, } \\
\text { Spain }\end{array}$ & $\begin{array}{l}\text { Coastal, } \\
\text { temperate }\end{array}$ & 3 days + dating & 2000 & $0.52 \pm 0.08$ & $\begin{array}{l}\text { July- } \\
\text { October }\end{array}$ & $1.3-3.0$ & $2-6$ & This study* \\
\hline Scallop & $\begin{array}{l}\text { Comptopallium } \\
\text { radula }\end{array}$ & calcite & $\begin{array}{l}\text { Nouméa, } \\
\text { New Caledonia }\end{array}$ & $\begin{array}{l}\text { Coastal, } \\
\text { tropical }\end{array}$ & 4 days + dating & $2002-2003$ & 0.52 & $\begin{array}{l}\text { January, March, May, } \\
\text { August, September }\end{array}$ & $0.92-3.7$ & $2-10$ & Thébault (2005)* \\
\hline Scallop & $\begin{array}{l}\text { Argopecten } \\
\text { purpuratus }\end{array}$ & calcite & $\begin{array}{l}\text { Rinconada bay, } \\
\text { Chile }\end{array}$ & Coastal & Some days & 1999 & 0.7 & June-July & $3-12$ & $4-17$ & Thébault (2005) \\
\hline Mussel & Mytilus edulis & calcite & $\begin{array}{l}\text { The Netherlands, } \\
\text { Schelde estuary }\end{array}$ & $\begin{array}{l}\text { Coastal, } \\
\text { temperate }\end{array}$ & Monthly or better & 1995-2003 & 3 & Spring & $20-70$ & $7-23$ & $\begin{array}{l}\text { Vander Putten et al. (1999); } \\
\text { Vander Putten et al. (2000); } \\
\text { Gillikin et al. (2006)* }\end{array}$ \\
\hline Oyster & $\begin{array}{l}\text { Isognomon } \\
\text { ephippium }\end{array}$ & $\begin{array}{l}\text { calcite } \\
\text { aragonite }\end{array}$ & $\begin{array}{l}\text { Kenya, Tudor estuary } \\
\text { or mangroves }\end{array}$ & $\begin{array}{l}\text { Coastal, } \\
\text { tropical }\end{array}$ & Monthly or better 1 & 1991-1998 & 1 & Monsoon period & $5-11$ & $5-11$ & Lazareth et al. (2003) \\
\hline Clam & $\begin{array}{l}\text { Mesodesma } \\
\text { donacium }\end{array}$ & aragonite & Peru & Coastal & Monthly or better & 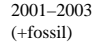 & $2(850)$ & $\begin{array}{l}\text { January, May, } \\
\text { September (?) }\end{array}$ & $\begin{array}{l}10-30 \\
(1500)\end{array}$ & 5-10 (2) & Carré et al. (2006) \\
\hline Clam & $\begin{array}{l}\text { Chino } \\
\text { subrugosa }\end{array}$ & aragonite & Peru & Coastal & Monthly or better & 2001-2004 & 10 & $\begin{array}{l}\text { January, November, } \\
\text { December }\end{array}$ & $30-40$ & $3-4$ & Carré et al. (2006) \\
\hline Clam & $\begin{array}{l}\text { Mercenaria } \\
\text { mercenaria }\end{array}$ & aragonite & $\begin{array}{l}\text { USA, } \\
\text { Delaware Bay }\end{array}$ & $\begin{array}{l}\text { Coastal, } \\
\text { temperate }\end{array}$ & Monthly or better & $\begin{array}{l}\text { 1984-1992 } \\
\text { (+fossil) }\end{array}$ & $2(5)$ & Spring & $\begin{array}{l}5-20 \\
(15-35)\end{array}$ & $\begin{array}{l}3-10 \\
(3-7)\end{array}$ & Stecher et al. (1996) \\
\hline Clam & $\begin{array}{l}\text { Spisula } \\
\text { solidissima }\end{array}$ & aragonite & $\begin{array}{l}\text { USA, } \\
\text { Chesapeake Bay }\end{array}$ & $\begin{array}{l}\text { Coastal, } \\
\text { temperate }\end{array}$ & Monthly or better & 1980-1982 & 2 & Spring & $5-40$ & $3-20$ & Stecher et al. (1996) \\
\hline Clam & $\begin{array}{l}\text { Ensis } \\
\text { siliqua }\end{array}$ & aragonite & Great Britain & $\begin{array}{l}\text { Coastal, } \\
\text { temperate }\end{array}$ & Monthly or better & 1991-1998 & $1-5$ & $\begin{array}{l}\text { Usually late } \\
\text { summer }\end{array}$ & $2-20$ & $2-4$ & Pearce and Mann (2006) \\
\hline Clam & $\begin{array}{l}\text { Arctica } \\
\text { Islandica }\end{array}$ & aragonite & German Bight & $\begin{array}{l}\text { Coastal, } \\
\text { temperate }\end{array}$ & Monthly or better & $1858-2002$ & $1-3$ & Spring & $10-70$ & $3-20$ & Epplé (2004) \\
\hline Clam & $\begin{array}{l}\text { Saxidomus } \\
\text { giganteus }\end{array}$ & aragonite & $\begin{array}{l}\text { Puget Sound, } \\
\text { Washington, USA }\end{array}$ & $\begin{array}{l}\text { Coastal, } \\
\text { temperate }\end{array}$ & Monthly or better & 1992-2001 & 1 & $\begin{array}{l}\text { Spring or } \\
\text { Summer }\end{array}$ & $5-35$ & $5-35$ & Gillikin et al. (2008)* \\
\hline Clam & $\begin{array}{l}\text { Calyptogena pacifica } \\
\text { or kilmeri }\end{array}$ & aragonite & $\begin{array}{l}\text { Monterey Canyon and } \\
\text { Cascadia margin, USA }\end{array}$ & $\begin{array}{l}\text { Coastal, } \\
\text { temperate }\end{array}$ & Annual & 1987-1997 & $1-2$ & $\begin{array}{l}\text { During cold } \\
\text { fluid discharge }\end{array}$ & $5-80$ & $5-80$ & Torres et al. (2001) \\
\hline Clam & $\begin{array}{l}\text { Corbula } \\
\text { amurensis }\end{array}$ & aragonite & $\begin{array}{l}\text { San Francisco Bay, } \\
\text { USA }\end{array}$ & $\begin{array}{l}\text { Estuarine, } \\
\text { temperate }\end{array}$ & No dating & 1991-1996 & Ratios & ranging from few to less & than $200 \mu \mathrm{mol} / \mathrm{mol}$ & & Takesue et al. (2008) \\
\hline
\end{tabular}

* represent analyses performed with $\mathrm{CaCO}_{3}$ standards.

were compared with variations of $\mathrm{Ba}$ concentrations in seawater (Fig. 4a-b). Variations of dissolved and particulate $\mathrm{Ba}$ exhibit concentrations ranging, respectively, from 45 to $100 \mathrm{nmol} / \mathrm{l}$ and 0.7 to $9 \mathrm{nmol} / \mathrm{l}$, and averaging 50 and $2 \mathrm{nmol} / \mathrm{l}$. The background $([\mathrm{Ba}] /[\mathrm{Ca}])$ ratio in dissolved seawater in 2000 is about $5.2 \pm 0.5 \mu \mathrm{mol} / \mathrm{mol}$ (Lorrain, 2002) which is slightly different than the value reported in 2003 $(3.8 \mu \mathrm{mol} / \mathrm{mol})$ (Gillikin et al., 2008). The ratio calculated in 2003 corresponds to only 3 measurements, which is considerably less than in $2000(n=43)$ and may explain such difference. The major pool of $\mathrm{Ba}$ in the seawater at the SWI originates from the dissolved phase. Background $([\mathrm{Ba}] /[\mathrm{Ca}])_{\text {shell }}$ ratios in Mytilus edulis mussel shells were previously demonstrated to be directly related to the $([\mathrm{Ba}] /[\mathrm{Ca}])_{s w}$ ratios of the water in which they grew (Gillikin et al., 2006). For the same scallop species (Pecten maximus) and in the same sampling site (Bay of Brest), the partition coefficient $D_{\mathrm{Ba}}$ was reported to be 0.18 in 2003 and similar to those obtained for Mytilus edulis mussels or Saxidomus giganteus clams in other coastal temperate ecosystems (Gillikin et al., 2006, 2008). In our study, the shell Ba partition coefficient $\left(D_{\mathrm{Ba}}\right)$, evaluated in 2000 using the $([\mathrm{Ba}] /[\mathrm{Ca}])_{s w}$ ratio in the dissolved seawater phase and the background $([\mathrm{Ba}] /[\mathrm{Ca}])_{\text {shell }}$ ratio measured in shells, is about $D_{\mathrm{Ba}}=0.11 \pm 0.03$ (Barats, 2006). Taking into account the difference of analytical methods, these results are all similar to those obtained previously as reported in the literature. Background $([\mathrm{Ba}] /[\mathrm{Ca}])_{\text {shell }}$ ratios in P. maximus shells may thus be considered as a relevant proxy of $\mathrm{Ba}$ aqueous concentrations.

\subsubsection{Transient processes related to $([\mathrm{Ba}] /[\mathrm{Ca}])_{\text {shell }}$ maximum events}

\section{The origin of $([\mathrm{Ba}] /[\mathrm{Ca}])_{\text {shell }}$ scallop shell maxima}

Summer $([\mathrm{Ba}] /[\mathrm{Ca}])_{\text {shell }}$ maxima underline an important additional source of $\mathrm{Ba}$ at the SWI, which in turn will influence both dissolved and particulate Ba concentrations in the scallop habitat. In 2000, dissolved and particulate Ba exhibited increasing seawater concentrations at the end of July concomitant to the first increase of $([\mathrm{Ba}] /[\mathrm{Ca}])_{\text {shell }}$ ratio (Fig. 4ab) (Lorrain, 2002). This maximum of $([\mathrm{Ba}] /[\mathrm{Ca}])_{\text {shell }}$ ratio is 2.6 times higher than the background one, whereas dissolved seawater Ba concentration is 1.5 times higher than the background one. The increase of dissolved Ba concentration is probably not sufficient to explain the increase in skeletal $([\mathrm{Ba}] /[\mathrm{Ca}])_{\text {shell }}$ content. At the end of July, particulate 
Ba concentration increases up to 5 times the background content. This significant increase of particulate Ba may provide additional inputs of $\mathrm{Ba}$ at the SWI. As bivalves are non specific filter feeders, these additional inputs of Ba-rich particles at the SWI, in the surrounding scallop environment, are supposedly ingested as food, in part digested, transferred to the extrapalleal fluid, and finally archived in the shell (Stecher et al., 1996; Vander Putten et al., 2000; Lorrain, 2002; Gillikin et al., 2006).

A proposed pelagic biogenic process as the initial cause of Ba-rich particles at the SWI and subsequent $([\mathrm{Ba}] /[\mathrm{Ca}])_{\text {shell }}$ maxima

The occurrence and the amplitude of summer $([\mathrm{Ba}] /[\mathrm{Ca}])_{\text {shell }}$ peaks were intensively examined in the Bay of Brest over 7 years (1998-2004) because of a regular and complete monitoring of physiological (growth) and environmental parameters (hydrological, biological, chemical).

$([\mathrm{Ba}] /[\mathrm{Ca}])_{\text {shell }}$ variation as a result of environmental changes: The influence of the shell growth rate on $([\mathrm{Ba}] /[\mathrm{Ca}])_{\text {shell }}$ peaks is studied to take in account a potential external environmental control. Decreases of shell growth rate were previously considered to be mainly induced by lower seawater temperature or the occurrence of specific phytoplankton blooms (Chauvaud et al., 1998; Lorrain et al., 2000). In 2002 (4th peak) or in 2004 (1st and 2nd peaks), such decreases of shell growth rate occurr simultaneous to $([\mathrm{Ba}] /[\mathrm{Ca}])_{\text {shell }}$ maxima. For other investigated years, $([\mathrm{Ba}] /[\mathrm{Ca}])_{\text {shell }}$ maxima are not coincident to any shell growth anomaly. $([\mathrm{Ba}] /[\mathrm{Ca}])_{\text {shell }}$ maxima cannot thus be directly related to minima of shell growth rate.

The specific survey in 2000 supports rather supplementary dissolved and particulate Ba inputs at the SWI in summer, subsequently taken up by the bivalve to explain $([\mathrm{Ba}] /[\mathrm{Ca}])_{\text {shell }}$ maxima. There are different potential sources providing these $\mathrm{Ba}$ inputs at the SWI: either related to a benthic Ba recycling and remobilization processes, or pelagic $\mathrm{Ba}$ enrichments originating from anomalous ecological changes, or a coupling of both phenomena.

$([\mathrm{Ba}] /[\mathrm{Ca}])_{\text {shell }}$ variation as a result of a biogenic pelagic process: First, the examination of hydrological conditions (seawater temperature and salinity) reveals no significant similarity neither with the occurrence, nor with the amplitude of maximum $([\mathrm{Ba}] /[\mathrm{Ca}])_{\text {shell }}$ ratios. In the Bay of Brest, the role of hydroclimatic events (flood and/or resuspension) was previously investigated in detail (Lorrain, 2002) and did not exhibit any influence on the shell growth and chemistry. Ba inputs due to such hydroclimatic events are thus improbable to explain these Ba particulate inputs at the SWI. Benthic release due to more reducing conditions at the SWI can also occur, but these should preferentially release dissolved components. More reductive condition at the SWI, as observed in a eutrophicated estuarine bay (Seine Bay), promote the benthic release of dissolved Mn which was demonstrated
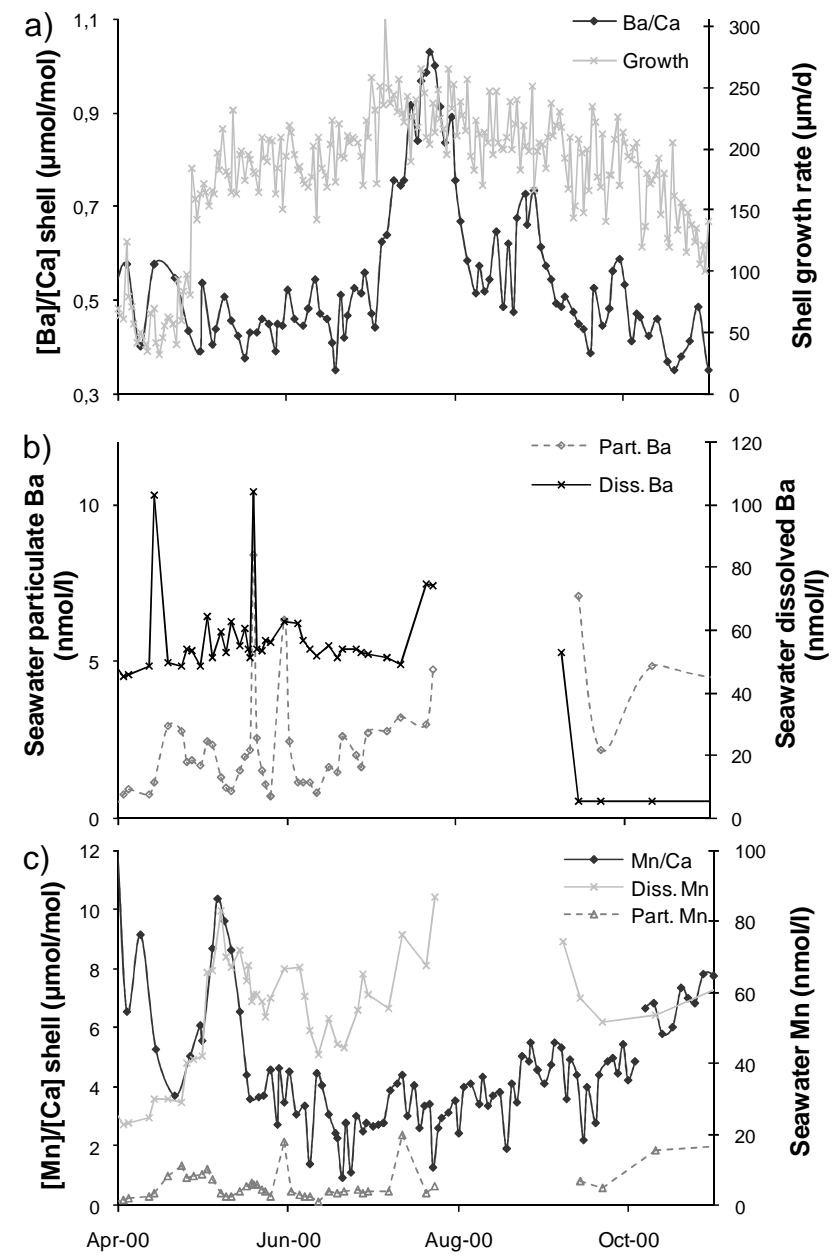

Fig. 4. Mean $([\mathrm{Ba}] /[\mathrm{Ca}])$ shell shell profiles $(n=3)$ obtained during 2000 in the Bay of Brest (a) 750 compared with (b) particulate and dissolved $\mathrm{Ba}$ concentrations (nmol/l) in dissolved seawater 751 (bottom seawater: $1 \mathrm{~m}$ of the SWI) and (c) mean shell ([Mn]/[Ca])shell profiles, dissolved and 752 particulate Mn concentrations (nmol/l).

to induce increasing shell Mn content in summer (Barats et al., 2008). In 2000, skeletal Mn concentrations are relatively constant, concurrent with constant seawater particulate $\mathrm{Mn}$ content and a low increase of Mn concentration in the dissolved phase (Fig. 4c). The dissolved oxygen concentrations (annual average: $6.1 \pm 0.5 \mathrm{ml} / 1$; and summer average from mid-May to mid-September: $6.0 \pm 0.3 \mathrm{ml} / \mathrm{l}$ ) are constant in the Bay of Brest, suggesting well oxygenated seawater. For other years, even if seawater Mn measurements are not available, archived shell Mn supports stable content during $([\mathrm{Ba}] /[\mathrm{Ca}])_{\text {shell }}$ maxima, contrary to benthic Ba remobilisation due to more reductive conditions. The origin of $\mathrm{Ba}$ inputs at the SWI is thus rather initiated by a pelagic biogenic process (Lorrain, 2002).

$([\mathrm{Ba}] /[\mathrm{Ca}])_{\text {shell }}$ variation as a result of phytoplankton biomass dynamic: The phytoplankton dynamics are 
Table 3. : Single correlations and multiple regression analyses outlining significant relationships between the amplitude of maximum $[\mathrm{Ba} / \mathrm{Ca}]_{\text {shell }}$ ratios $(\mu \mathrm{mol} / \mathrm{mol})$ and environmental variables (Stabox Pro software for Windows Ver. 6, Grimmer Software. France).

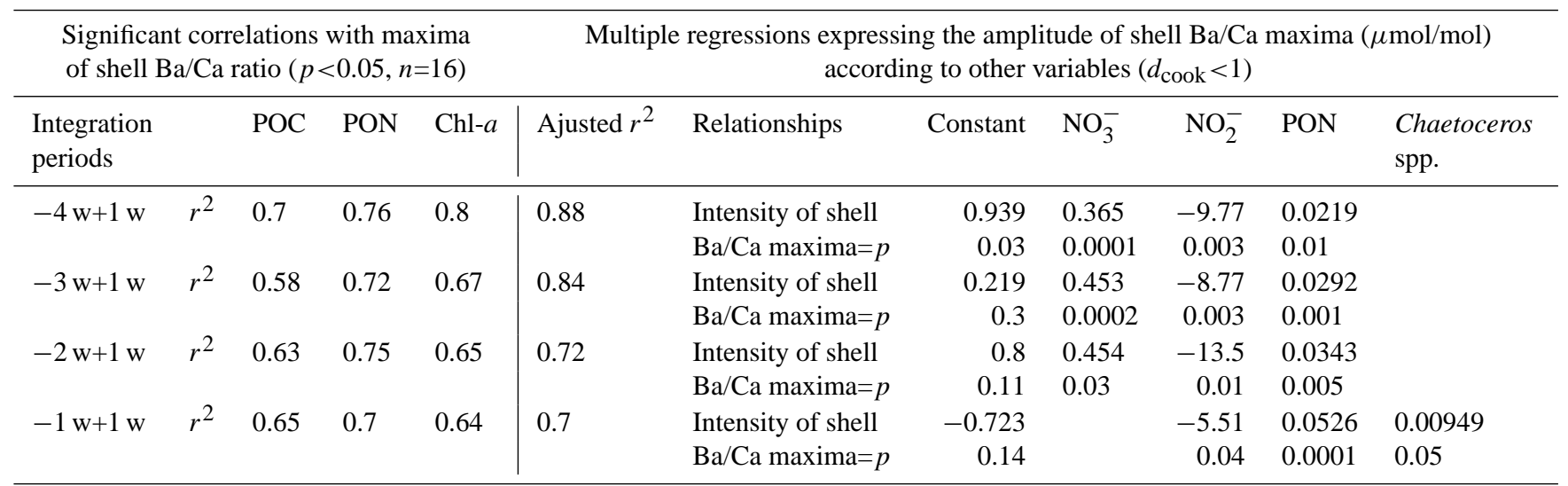

particularly examined because phytoplankton is an important vector for the vertical transport of $\mathrm{Ba}$ in oceans (Dehairs et al., 1980, 1991, 1997; Bishop, 1988). The Chl- $a$ concentrations in the seawater that are supposed to reflect phytoplankton biomass, exhibited a general pattern with an intense maximum occurring in spring and later ones somewhat smaller in late summer (Fig. 3). Phytoplankton blooms generally occurred in the month preceding $([\mathrm{Ba}] /[\mathrm{Ca}])_{\text {shell }}$ maxima. In 1998 and 2003, ([Ba]/[Ca]) shell profiles revealed a surprising analogy with the variations of Chl- $a$ concentrations: 2 maximum events with the first most intense one and during similar time periods. Time lag between the occurrence of maximum Chl- $a$ concentration and maxima of $([\mathrm{Ba}] /[\mathrm{Ca}])_{\text {shell }}$ ratio ranged from 1 week to 3 months (in 2003). In 1999 and 2002, ([Ba]/[Ca] $)_{\text {shell maxima occurred }}$ coincident to periods of higher Chl- $a$ concentration, but their profile shapes were totally different. In 2001, a particularly productive year, the maxima of $([\mathrm{Ba}] /[\mathrm{Ca}])_{\text {shell }}$ peaks were surprisingly weak; whereas in 2004, the year with lowest productivity, the intensity of $([\mathrm{Ba}] /[\mathrm{Ca}])_{\text {shell }}$ peaks was important, higher than in 2001. These results highlight that the extent of $([\mathrm{Ba}] /[\mathrm{Ca}])_{\text {shell }}$ maxima are not directly related to Chl- $a$ concentration in seawater. Consequently, archived Ba in shells cannot be considered as a proxy of the bulk photosynthetic biomass in coastal waters. Statistical data treatment reveals however significant single correlations between the amplitude of maximum $([\mathrm{Ba}] /[\mathrm{Ca}])_{\text {shell }}$ ratios and the maximum of Chl- $a$ concentrations during the different integrated periods $\left(r^{2}>0.64, p<0.05, n=16\right.$; Table 3$)$, thus suggesting the influence of the total biomass on the amplitude of $([\mathrm{Ba}] /[\mathrm{Ca}])_{\text {shell maxima. }}$

$([\mathrm{Ba}] /[\mathrm{Ca}])_{\text {shell }}$ variation as a result of phytoplankton species dynamic: Specific attention is now focussed on the phytoplankton composition during the whole summer period. Among the hundred species, no particular species can be identified as recurrent. However, species of only two genera are revealed recurrent and dominant: diatoms of Chaetoceros and dinoflagellates of Gymnodynium. Other genera are only found to be punctual and often minor during the period of increased $([\mathrm{Ba}] /[\mathrm{Ca}])_{\text {shell }}$ ratios. In 1998, 1999, 2001 and 2002, the first maximum of $([\mathrm{Ba}] /[\mathrm{Ca}])_{\text {shell }}$ occurs simultaneously or within a short time lag of dominant Chaetoceros blooms (Fig. 5). The second maxima are in turn found to mainly occur during Gymnodynium blooms (Fig. 5). In 2000, Chaetoceros exhibit 3 blooms, the most intense over the 7-year period (Fig. 5). This second maxima can only be associated to a maximum of $([\mathrm{Ba}] /[\mathrm{Ca}])_{\text {shell }}$ ratios, the lowest one over the 7-year period. In 2001, a Gymnodynium bloom, the most intense over 7-year period, occurs concurrent to $([\mathrm{Ba}] /[\mathrm{Ca}])_{\text {shell }}$ ratios close to the background concentration (Fig. 5). These 2 specific blooms cannot thus influence the amplitude or the occurrence of maximum $([\mathrm{Ba}] /[\mathrm{Ca}])_{\text {shell }}$ ratios. Neither specific species, nor these two genera (Chaetoceros and Gymnodynium), nor these two largest group of eukaryotic algae (diatoms or dinoflagellates), nor the total phytoplankton abundance are directly correlated with these $([\mathrm{Ba}] /[\mathrm{Ca}])_{\text {shell }}$ maximum events.

$([\mathrm{Ba}] /[\mathrm{Ca}])_{\text {shell }}$ variation as a result of particulate biogenic material production: Among major chemical parameters examined (i.e. dissolved oxygen, nutrients, POC, PON), only POC and PON concentrations exhibit similar transient events such as maxima in $([\mathrm{Ba}] /[\mathrm{Ca}])_{\text {shell ratio (Fig. 5). }}$. Considering maximum concentrations of POC and PON in the month preceding the maximum $([\mathrm{Ba}] /[\mathrm{Ca}])_{\text {shell }}$ ratios, single correlations are obtained between the amplitude of maximum $([\mathrm{Ba}] /[\mathrm{Ca}])_{\text {shell }}$ ratios and maxima of POC and PON concentrations $\left(r^{2}>0.58, p<0.05, n=16\right)$ (Table 3$)$. Multiple regression analyses reveal a systematic relationship expressing the amplitude of maximum $([\mathrm{Ba}] /[\mathrm{Ca}])_{\text {shell }}$ ratio as a function of nitrates, $\mathrm{PON}$ and nitrite contents 
(a)
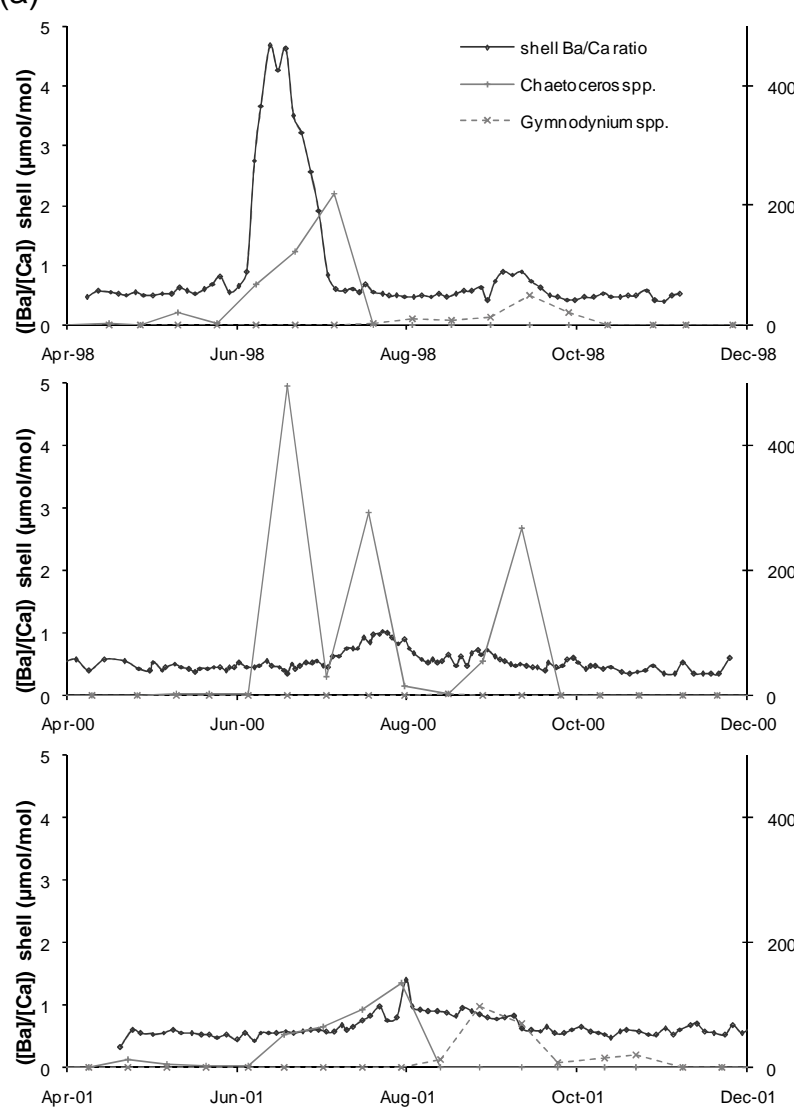

(b)
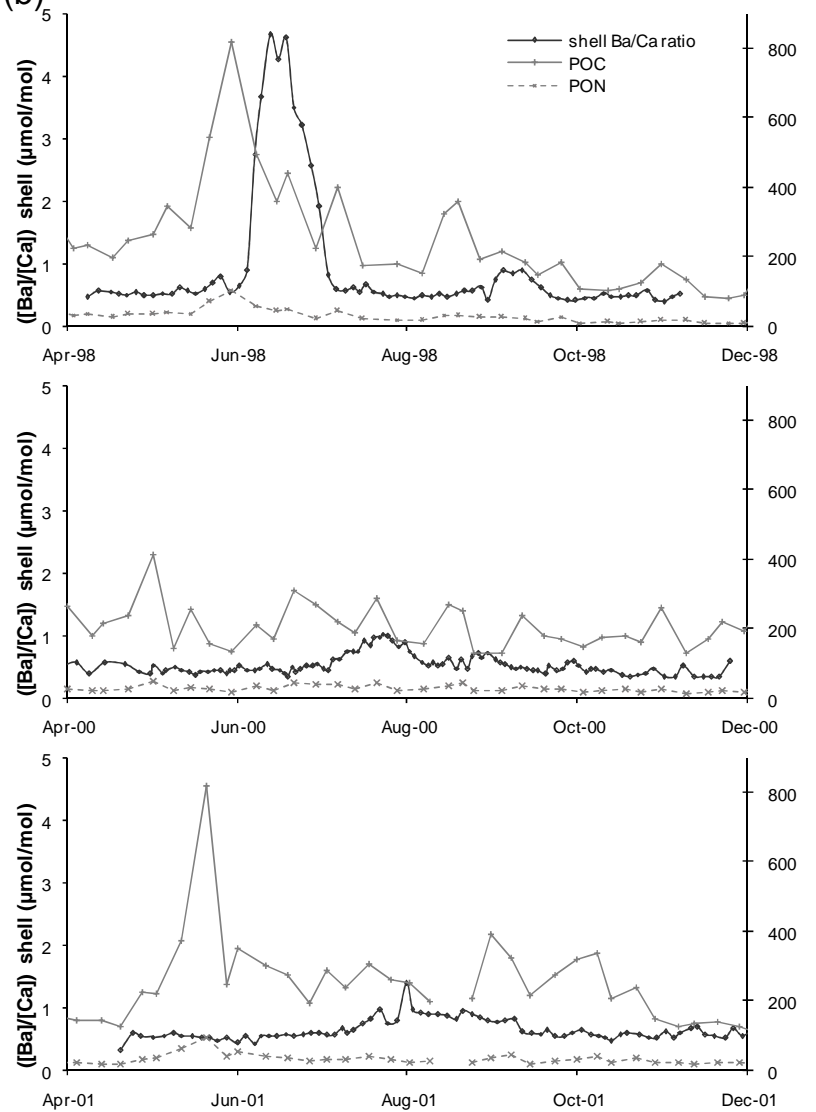

Fig. 5. Example of variations of $([\mathrm{Ba}] /[\mathrm{Ca}])_{\text {shell }}$ ratios for 3 years $(1998,2000,2001)$ in shells from the Bay of Brest (France) according to: (a) two phytoplankton genera (Chaetoceros and Gymnodynium), (b) particulate organic carbon (POC) and particulate organic nitrogen $(\mathrm{PON})$ concentrations $(\mu \mathrm{g} / \mathrm{l})$ in seawater.

in the seawater $\left(r^{2}>0.70, p<0.30, n=16\right)$ (Table 3). The amplitude of maximum $([\mathrm{Ba}] /[\mathrm{Ca}])_{\text {shell }}$ ratio is higher during increasing nitrate and PON contents in seawater and during decreasing concentrations of nitrates. These statistical relationships agree with an initial pelagic biogenic process involved in supplementary Ba inputs at the SWI to explain the maximum $([\mathrm{Ba}] /[\mathrm{Ca}])_{\text {shell }}$ events. In the month preceding $([\mathrm{Ba}] /[\mathrm{Ca}])_{\text {shell }}$ maxima, diatom blooms are usually dominant. These taxa grow rapidly when nitrate is available. They have a high uptake capacity for nitrates, even at low concentrations (Carter et al., 2005). Nutrient availability governs the amplitude of phytoplankton blooms and its composition (Chauvaud et al., 2000; Le Pape et al., 1996; Ragueneau et al., 2002). However, higher dissolved inorganic nitrogen in the seawater during the month preceding $([\mathrm{Ba}] /[\mathrm{Ca}])_{\text {shell }}$ maxima promotes the primary productivity (Carter et al., 2005). Higher phytoplankton biomass induces then the production of higher inputs of PON in seawater. Periods of higher summer productivity and post-bloom conditions are prone to amplify the maximum $([\mathrm{Ba}] /[\mathrm{Ca}])_{\text {shell }}$ ratio.
Processes involved in Ba-enrichment at the SWI that evidence subsequent $([\mathrm{Ba}] /[\mathrm{Ca}])_{\text {shell }}$ maxima

This study underlines the influence of an initial pelagic biological bloom process on the occurrence and the amplitude of maximum $([\mathrm{Ba}] /[\mathrm{Ca}])_{\text {shell. }}$. These processes are nonspecific to either phytoplankton species or genera, and rather related to post-bloom summer conditions. The episodic ([Ba]/[Ca] $)_{\text {shell }}$ maxima in P. maximus shells are supposed to be induced by a trophic uptake of supplementary particulate $\mathrm{Ba}$ inputs at the SWI. These Ba-enriched particles may originate either from scavenging of phytoplankton-derived particles or from a benthic post-bloom remobilization. A pathway leading to particulate $\mathrm{Ba}$ enrichment within the water column and scavenged to the SWI is most plausible (Ganeshram et al., 2003; Sternberg et al., 2005). Different pathways were proposed to explain $\mathrm{Ba}$ enrichment in particles at the SWI: such as Ba adsorption in phytoplankton cells, barite formation during phytoplankton decay, Ba enrichment in exopolymeric substances (EPS), or Ba adsorption onto mineral oxides formed within diatom biogenic particles. 
Chaetoceros spp. blooms are usually dominant during the month preceding maximum $([\mathrm{Ba}] /[\mathrm{Ca}])_{\text {shell. }}$ The agglomeration of EPS is specifically reported during bacterial decomposition of these Chaetoceros spp. blooms, as promoted in response to nutritional stress. These conditions are indeed collated in this study, which systematically display depleted concentrations of nitrates and nitrites in seawater before the most significant maximum $[\mathrm{Ba}] /[\mathrm{Ca}])_{\text {shell }}$ (Passow and Alldredge, 1995; Stecher and Kogut, 1999; Alldredge et al., 1995; Thornton, 2002). Both colloidal organic material and EPS are particularly enriched in Ba by five orders of magnitude (Quigley et al., 2002). Ba-rich EPS may thus support inputs of Ba-enriched particles at the SWI.

Among the different pathways such as Ba adsorption in phytoplankton cells, barite formation during phytoplankton decay, Ba enrichment in EPS, or Ba adsorption onto mineral oxides formed within diatom biogenic particles, the exact processes inducing $\mathrm{Ba}$ enrichment in particles at the SWI cannot be clearly identified. This study however supports the concept that a pelagic biogenic process initiates the delivery and subsequent bivalve uptake of Ba-enriched particles leading to incorporation into the individual striae of scallop shells.

\section{Conclusions}

Barium shell profiles from Great Scallops obtained in this methodical survey in temperate waters agree with those of other bivalve species previously investigated and demonstrate their reproducibility, recurrence and ubiquity in such coastal environments. This study confirms that $([\mathrm{Ba}] /[\mathrm{Ca}])_{\text {shell }}$ profiles are characterized by a relatively constant background mainly governed by the ambient seawater dissolved $\mathrm{Ba}$, and the occurrence of distinct summer $([\mathrm{Ba}] /[\mathrm{Ca}])_{\text {shell }}$ maxima. In 2000, Ba measurements in seawater allowed identifying that particulate $\mathrm{Ba}$ inputs can be the dominant pathway explaining $([\mathrm{Ba}] /[\mathrm{Ca}])_{\text {shell }}$ maxima. Pelagic biogenic processes are supposed to initiate seawater Ba enrichment at the SWI, subsequently taken up by scallops and translated by increased $([\mathrm{Ba}] /[\mathrm{Ca}])_{\text {shell }}$ ratios. Examination of the complete dataset (1998-2004) demonstrates that $([\mathrm{Ba}] /[\mathrm{Ca}])_{\text {shell }}$ maxima occurred under summer post-bloom conditions, such that their amplitude depends on nitrogen cycle: both particulate organic nitrogen and the turnover of dissolved nitrogen species. This whole dataset demonstrates that: (1) records of maximum $([\mathrm{Ba}] /[\mathrm{Ca}])_{\text {shell }}$ ratio cannot be used directly as a relevant paleo productive tracer, and (2) complex processes occur in the pelagic/benthic Ba cycle and are responsible for significant $\mathrm{Ba}$ inputs at the SWI. If these processes are better constrained, scallop $([\mathrm{Ba}] /[\mathrm{Ca}])_{\text {shell }}$ records could provide a proxy of Ba biogeochemistry with high temporal resolution in coastal environments.
Acknowledgements. This work was supported in the framework of two research programs: ACI PECTEN (French Ministère de la Recherche) and "Suivi Erika" (INERIS, French Ministère de l'Environnement). Thermo Electron Company is thanked for the loan of the ICP-MS. A. B. acknowledges the Aquitaine Region (ORQUE project) for her Doctoral fellowship. A. B. thanks G. Sinquin from the Groupe de Microscopie Electronique (Université de Bretagne Occidentale, France) for his help concerning the SEM (scanning electron microscopy) photography, and D. Cardinal from Department of Geology (Royal Museum for Central Africa, Belgium) for his help in analyses of particulate $\mathrm{Ba}$ in seawater.

Edited by: S. Bouillon

\section{References}

Alldredge, A. L., Gotschalk, C., Passow, U., and Riebesell, U.: Mass aggregation of diatom blooms: Insights from a mesocosm study, Deep-Sea Res., Pt. II, 42, 9-27, 1995.

Barats, A.: Micro analyse quantitative des éléments traces dans la calcite de la coquille Saint Jacques Pecten maximus par Ablation Laser et Spectrométrie de Masse à Plasma Inductif Couplé (LA-ICP-MS): une archive journalière de la biogéochimie des environnements côtiers tempérés., Laboratoire de Chimie Analytique Bio Inorganique et Environnement, Université de Pau et des Pays de l'Adour, Pau, France, 301 pp., 2006.

Barats, A., Pécheyran, C., Amouroux, D., Dubascoux, S., Chauvaud, L., and Donard, O. F. X.: Matrix-matched quantitative trace element analysis in calcium carbonate shells by Laser Ablation ICP-MS: application to the determination of daily scale profiles in scallop shell (Pecten maximus), Anal. Bioanal. Chem., 387, 1131-1140, 2007.

Barats, A., Amouroux, D., Pécheyran, C., Chauvaud, L., and Donard, O. F. X.: High-frequency archives of manganese inputs to coastal waters (Bay of Seine, France) resolved by the LA-ICPMS analysis of calcitic growth layers along scallop shells (Pecten maximus), Environ. Sci. Technol., 42, 86-92, 2008.

Belloto, V. R. and Mikeley, N.: Improvement in calibration procedures for the quantitative determination of trace elements in carbonate material (mussel shells) by laser ablation ICP-MS, Fresenius' J. Anal. Chem., 367, 635-640, 2000.

Bishop, J. K. B.: The barite-opal-organic carbon association in oceanic particulate matter, Nature, 332, 341-343, 1988.

Carré, M., Bentaleb, I., Bruguier, O., Ordinola, E., Barrett, N. T., and Fontugne, M.: Calcification rate influence on trace element concentrations in aragonitic bivalve shells: Evidences and mechanisms, Geochim. Cosmochim. Acta, 70, 4906-4920, 2006.

Carroll, M., Romanek, C., and Paddock, L.: The relationship between the hydrogen and oxygen isotopes of freshwater bivalve shells and their home streams, Chem. Geol., 234, 211-222, 2006.

Carter, C. M., Ross, A. H., Schiel, D. R., Howard-Williams, C., and Hayden, B.: In situ microcosm experiments on the influence of nitrate and light on phytoplankton community composition, J. Exp. Mar. Biol. Ecol., 326, 1-13, 2005.

Chauvaud, L.: La coquille Saint Jacques en rade de Brest: un modèle biologique d'étude des réponses de la faune benthique aux fluctuations de l'environnement, Université de Bretagne Occidentale, Brest, France, 1998. 
Chauvaud, L., Thouzeau, G., and Paulet, Y. M.: Effects of environmental factors on the daily growth rate of Pecten maximus juveniles in the Bay of Brest (France), J. Exp. Mar. Biol. Ecol., 227, 83-111, 1998.

Chauvaud, L., Jean, F., Ragueneau, O., and Thouzeau, G.: Longterm variation of the Bay of Brest ecosystem: benthic-pelagic coupling revisited, Mar. Ecol.-Prog. Ser., 200, 35-48, 2000.

Chauvaud, L., Lorrain, A., Dunbar, R. D., Paulet, Y. M., Thouzeau, G., Jean, F., Guarini, J.-M., and Mucciarone, D.: Shell of the Great Scallop Pecten maximus as a high-frequency archive of paleoenvironmental changes, Geochem. Geophy. Geosyst., 6, 1-15, 2005.

Coffey, M., Dehairs, F., Collette, O., Luther, G., Church, T., and Jickells, T.: The behaviour of dissolved barium in estuaries, Estuar. Coast. Shelf Sc., 45, 113-121, 1997.

de Vries, M. C., Gillanders, B. M., and Elsdon, T. S.: Facilitation of barium uptake into fish otoliths: Influence of strontium concentration and salinity, Geochim. Cosmochim. Acta, 69, 4061-4072, 2005.

Dehairs, F., Chesselet, R., and Jedwab, J.: Discrete suspended particles of barite and the barium cycle in the open ocean, Earth Planet. Sci. Lett., 49, 528-550, 1980.

Dehairs, F., Stroobants, N., and Goeyens, L.: Suspended barite as a tracer of biological activity in the Southern Ocean, Mar. Chem., 35, 399-410, 1991.

Dehairs, F., Shopova, D., Ober, S., Veth, C., and Goeyens, L.: Particulate barium stocks and oxygen consumption in the Southern Ocean mesopelagic water column during spring and early summer: relationship with export production, Deep-Sea Res. Pt. II, 44, 497-516, 1997.

Dehairs, F., Fagel, N., Antia, A. N., Peinert, R., Elskens, M., and Goeyens, L.: Export production in the Bay of Biscay as estimated from barium - barite in settling material: a comparison with new production, Deep-Sea Res. Pt. I, 47, 583-601, 2000.

Dodd, J. R.: Environmental control of strontium and magnesium in Mytilus, Geochim. Cosmochim. Acta, 29, 385-398, 1965.

Dymond, J. and Collier, R.: Particulate barium fluxes and their relationships to biological productivity, Deep-Sea Res. Pt. II, 43, 1283-1308, 1996.

Epplé, V. M.: High-resolution climate reconstruction for the Holocene based on growth chronologies of the bivalve Arctica islandica from the North Sea, Department of Geosciences, University of Bremen, Bremen, Germany, 101 pp., 2004.

Fisher, N. S., Guillard, R. R. L., and Bankston, D. C.: The accumulation of barium by marine phytoplankton grown in culture, $\mathrm{J}$. Mar. Res., 49, 339-354, 1991.

Fritz, L. W., Ragone, L. M., and Lutz, R. A.: Biomineralization of barite in the shell of the freshwater Asiatic clam Corbicula fluminea (Mollusca: Bivalvia), Limnol. Oceanogr., 35, 756-762, 1990.

Ganeshram, R. S., Francois, R., Commeau, J., and BrownLeger, S. L.: An experimental investigation of barite formation in seawater, Geochim. Cosmochim. Acta, 67, 2599-2605, doi:2510.1016/S0016-7037(2503)00164-00169, 2003.

Gillikin, D. P., De Ridder, F., Ulens, H., Elskens, M., Keppens, E., Baeyens, W., and Dehairs, F.: Assessing the reproducibility and reliability of estuarine bivalve shells (Saxidomus giganteus) for sea surface temperature reconstruction: Implications for paleoclimate studies, Palaeogeogr. Palaeoclim. Palaeoecol., 228, 70-
85, 2005.

Gillikin, D. P., Dehairs, F., Lorrain, A., Steenmans, D., Baeyens, W., and André, L.: Barium uptake into the shells of the common mussel (Mytilus edulis) and the potential for estuarine paleochemistry reconstruction, Geochim. Cosmochim. Acta, 70, 395407, 2006.

Gillikin, D. P., Lorrain, A., Paulet, Y. M., André, L., and Dehairs, F.: Synchronous barium peaks in high-resolution profiles of calcite and aragonite marine bivalve shells, Geo-Mar. Lett., 28, 351358, 2008.

Jeandel, C., Tachikawa, K., Bory, A., and Dehairs, F.: Biogenic barium in suspended and trapped material as tracer of export production NE Atlantic (EUMELI sites), Mar. Chem., 71, 125-142, 2000.

Klein, R. T., Lohmann, K. C., and Thayer, C. W.: Bivalve skeletons record sea-surface temperature and delta $\mathrm{O}-18$ via $\mathrm{Mg} / \mathrm{Ca}$ and O-18/O-16 ratios, Geology, 24, 415-418, 1996a.

Klein, R. T., Lohmann, K. C., and Thayer, C. W.: Sr/Ca and ${ }^{13} \mathrm{C} /{ }^{12} \mathrm{C}$ ratios in skeletal calcite of Mytilus trossulus: Covariation with metabolic rate, salinity, and carbon isotopic composition of seawater, Geochim. Cosmochim. Acta, 60, 4207-4221, $1996 b$.

Lazareth, C. E., Van Der Putten, E., André, L., and Dehairs, F.: High-resolution trace element profiles in shells of the mangrove bivalves Isognomon ephippium: a record of environmental spatio-temporal variations, Estuar. Coast. Shelf Sc., 57, 11031114, 2003.

Le Pape, O., Del Amo, Y., Menesguen, A., Aminot, A., Quequiner, B., and Treguer, P.: Resistance of a coastal ecosystem to increasing eutrophic conditions: the Bay of Brest (France), a semienclosed zone of Western Europe, Cont. Shelf Res., 16, 18851907, 1996.

Lea, D. W., Shen, G. T., and Boyle, E. A.: Coralline barium records temporal variability in equatorial Pacific upwelling, Nature, 340, 373-376, 1989.

Lea, D. W. and Martin, P. A.: A rapid mass spectrometric method for the simultaneous analysis of barium, cadmium, and strontium in foraminifera shells, Geochim. Cosmochim. Acta, 60, 31433149, 1996.

Levi-Kalisman, Y., Falini, G., Addadi, L., and Weiner, S.: Structure of the Nacreous Organic Matrix of a Bivalve Mollusk Shell Examined in the Hydrated State Using Cryo-TEM, J. Struct. Biol., 135, 8-17, 2001.

Lorens, R. B. and Bender, M. L.: The impact of solution chemistry on Mytilus edulis calcite and aragonite, Geochim. Cosmochim. Acta, 44, 1265-1278, 1980.

Lorrain, A., Paulet, Y. M., Chauvaud, L., Savoye, N., Nezan, E., and Guerin, L.: Growth anomalies in Pecten maximus from coastal waters (Bay of Brest, France): relationship with diatoms blooms, J. Mar. Biol. Assoc. UK, 2000.

Lorrain, A.: Utilisation de la coquille Saint-Jacques comme un traceur environnemental: approches biologique et biogéochimique, Institut Universitaire Européen de la Mer, Université de Bretagne Occidentale, Plouzané, 289 pp., 2002.

Lorrain, A., Gillikin, D. P., Paulet, Y.-M., Chauvaud, L., Le Mercier, A., Navez, J., and André, L.: Strong kinetic effects on $\mathrm{Sr} / \mathrm{Ca}$ ratios in the calcitic bivalve Pecten maximus, Geology, 33, 965968, 2005.

McCulloch, M., Fallon, S., Wyndham, T., Hendy, E., Lough, J., and 
Barnes, D.: Coral record of increased sediment flux to the inner Great Barrier Reef since European settlement, Nature, 421, 727730, 2003.

Passow, U. and Alldredge, A. L.: Aggregation of a diatom bloom in a mesocosm: The role of transparent exopolymer particles (TEP), Deep-Sea Res. Pt. II, 42, 99-109, 1995.

Paytan, A. and Kastner, M.: Benthic Ba fluxes in the central Equatorial Pacific, implications for the oceanic Ba cycle, Earth Planet. Sci. Lett., 142, 439-450, 1996.

Pearce, N. J. G. and Mann, V. L.: Trace metal variations in the shells of Ensis siliqua record pollution and environmental conditions in the sea to the west of mainland Britain, Mar. Pollut. Bull., 52, 739-755, 2006.

Quigley, M. S., Santschi, P. H., and Hung, C.-C.: Importance of acid polysaccharides for $234 \mathrm{Th}$ complexation to marine organic matter, Limnol. Oceanogr., 47, 367-377, 2002.

Ragueneau, O., Chauvaud, L., Leynaert, A., Thouzeau, G., Paulet, Y. M., Bonnet, S., Lorrain, A., Grall, J., Corvaisier, R., Le Hir, M., Jean, F., and Clavier, J.: Direct evidence of a biologically active coastal silicate pump: Ecological implications, Limnol. Oceanogr., 47, 1849-1854, 2002.

Rimstidt, J. D., Balog, A., and Webb, J.: Distribution of trace element between carbonate minerals and aqueous solutions, Geochim. Cosmochim. Acta., 62, 1851-1863, 1998.

Sarthou, G., Timmermans, K. R., Blain, S., and Treguer, P.: Growth physiology and fate of diatoms in the ocean: a review, J. Sea Res., 53, 25-42, 2005.

Shaw, T. J., Moore, W. S., Kloepfer, J., and Sochaski, M. A.: The flux of barium to the coastal waters of the southeastern USA: the importance of submarine groundwater discharge, Geochim. Cosmochim. Acta., 62, 3047-3054, 1998.

Sinclair, D. J. and McCulloch, M. T.: Corals record low mobile barium concentrations in the Burdekin River during the 1974 flood: evidence for limited Ba supply to rivers?, Palaeogeogr. Palaeoclim. Palaeoecol., 214, 155-174, 2004.

Sinclair, D. J.: Non-river flood barium signals in the skeletons of corals from coastal Queensland, Australia, Earth Planet. Sci. Lett., 237, 354-369, 2005.

Stecher, H. A., Krantz, D. E., Lord III, J. C., Luther III, G. W., and Bock, K. W.: Profiles of strontium and barium in Mercenaria mercenaria and Spisula solidissima, Geochim. Cosmochim. Acta., 60, 3445-3456, 1996.
Stecher, H. A. and Kogut, M. B.: Rapid barium removal in the Delaware estuary, Geochim. Cosmochim. Acta., 63, 1003-1012, 1999.

Sternberg, E., Tang, D., Ho, T. Y., Jeandel, C., and Morel, F. M. M.: Baryum uptake and adsorption in diatoms, Geochim. Cosmochim. Acta., 69, 2745-2752, 2005.

Takesue, R. K., Bacon, C. R., and Thompson, J. K.: Influences of organic matter and calcification rate on trace elements in aragonitic estuarine bivalve shells, Geochim. Cosmochim. Acta., 72, 5431-5445, 2008.

Thébault, J.: La coquille de Comptopallium radula (Bivalvia; Pectinidae), archive eulérienne haute-fréquence de la variabilité de l'environnement côtier tropical (Océan Pacifique), phD, Institut Universitaire Européen de la Mer, Université de Bretagne Occidentale, Plouzané, 277 pp., 2005.

Thornton, D. C. O.: Diatom aggregation in the sea: Mechanisms and ecological implications, Eur. J. Phycol., 37, 149-161, 2002.

Torres, M. E., Barry, J. P., Hubbard, D. A., and Suess, E.: Reconstructing the history of fluid flow at cold seep sites from $\mathrm{Ba} / \mathrm{Ca}$ ratios in vesicomyid clam shells, Limnol. Oceanogr., 46, 17011708, 2001.

Vander Putten, E., Dehairs, F., André, L., and Baeyens, W.: Quantitative in situ micro-analysis of minor and trace elements in biogenic calcite using infrared laser ablation-ICP-MS: a critical evaluation, Anal. Chim. Acta, 378, 261-272, 1999.

Vander Putten, E., Dehairs, F., Keppens, E., and Baeyens, W.: High resolution distribution of trace elements in the calcite shell layer of modern Mytilus edulis: Environmental and biological controls, Geochim. Cosmochim. Acta., 64, 997-1011, 2000.

Wyndham, T., Mc Culloch, M., Fallon, S., and Alibert, C.: Highresolution coral records of rare earth elements in coastal seawater: Biogeochemical cycling and a new environmental proxy, Geochim. Cosmochim. Acta., 68, 2067-2080, 2004.

Zacherl, D. C., Paradis, G., and Lea, D. W.: Barium and strontium uptake into larval protoconchs and statoliths of the marine neogastropod Kelletia kelletii, Geochim. Cosmochim. Acta., 67, 4091-4099, 2003. 